Not All Surges of Gross Capital Inflows Are Alike

Rogelio Mercado Jr.

TEP Working Paper No. 2016

December 2016

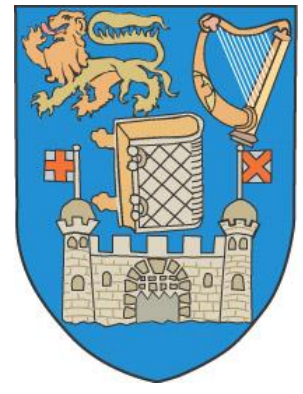

Trinity Economics Papers

Department of Economics

Trinity College Dublin 


\title{
Not All Surges of Gross Capital Inflows Are Alike
}

\author{
Rogelio Mercado Jr.* \\ Northumbria University
}

December 2016

\begin{abstract}
This paper looks into the transition of a surge episode to a stop episode and differentiates between two types of surges, namely surges that end in stops and surges that end in normal episodes. Previous studies on capital flows show that surges end in output contraction, crises, and reversals of capital inflows. However, when one looks closely at the data, more than half of surges end in normal episodes at least four quarters following the last surge quarter. This study focuses on global and domestic factors that strongly correlate with the transition of surges to either stop or normal episodes, as well as which factors correlate with the magnitude of gross inflows for these two types of surges. The results show that the higher likelihood of experiencing surges ending in stops is significantly correlated with lower global risk aversion and with higher domestic output gap. The estimates also indicate that surges ending in stops are different from surges ending in normal episodes. For instance, while global risk aversion and domestic credit are significant for both surges, larger gross capital inflows are significantly correlated with higher global commodity prices for surges ending in stops, but with lower commodity prices for surges ending in normal episodes.
\end{abstract}

Keywords: capital inflows, surges, stops, push and pull factors

JEL codes: F30, F32, F36

\footnotetext{
*Lecturer in Economics, Newcastle Business School, Northumbria University, Email: rogelio.mercado@northumbria.ac.uk

The author is highly indebted to Philip R. Lane for his valuable comments and suggestions. The author is also grateful to Agustin Benetrix, Vahagn Galstyan, Hiro Ito, and Frank Warnock for their comments and suggestions on this paper.
} 


\section{Introduction}

The literature on surges of capital flows highlights that changes in global and domestic factors can cause surges to end painfully either through output contraction and crises. ${ }^{1}$ Previous studies have identified two channels by which surges lead to hard landings. First, low global interest rates, strong growth in advanced countries, greater financial openness and policy reforms in host countries can trigger huge foreign capital inflows, particularly to emerging economies. This leads to higher consumption of non-tradable goods which raises relative prices causing exchange rate appreciation, lower net exports and output decline. Another channel is through the financial sector. Low global interest rates and perception of low financial risks trigger surges in capital inflows and facilitate domestic credit booms. As bank lending increases, the likelihood of banking and currency crises rises since lower borrowing costs exacerbates the moral hazard problem, riskier investments, and currency mismatches.

In addition, existing studies also indicate that surges lead to subsequent reversals of foreign capital inflows. Following a surge episode, capital inflows could reverse as global and domestic factors deteriorate alongside domestic output contraction and crises. Benigno et al. (2015), Calvo et al. (1993 and 1996), Kim et al. (2014), and Sula (2010) stress that the large reversal of capital inflows or "stops" are mostly preceded by large capital inflows or "surges". ${ }^{2}$ In fact, Calvo et al. (2006) define "systemic sudden stops" when stops are accompanied by output contraction. Benigno et al. (2015) and Sula (2010) find surges significantly increase the probability of experiencing stops. These studies describe the pattern of surges leading to stops in capital inflows.

It should, however, be pointed out that not all surges end in stops. It is possible that countries experiencing surges could allow for greater domestic adjustments, or global factors may not necessarily deteriorate substantially which would not entail large reversal of capital inflows. For instance, countries may respond with tighter macro-prudential framework or even with capital controls in dealing with surges and so it may not necessary lead to crises which could coincide with a stop episodes. Also, since surges are mostly driven by global factors, global economic conditions may not necessary deteriorate substantially following a surge episode. The case in point is the difference between surges that ended in stops in emerging economies in the 1990s and the global financial crisis of 2008-09. In the former, surges ended in stops for some emerging economies of East Asia, Russia, and some in Latin America. However, there were some recipients of capital bonanzas, such as Argentina, Indian, and Peru, in the 1990s that did not experience stop episode following the surge. In these economies, surges ended in normal episode because economic conditions in advanced economies did not deteriorate significantly in the mid-1990s, despite inherent vulnerabilities in these countries at that time. In contrast, most of the countries that experienced surges before the global financial crisis in 2008-09 experienced stop episodes because global conditions did not improve and in fact triggered crisis in some advanced economies. This clearly demonstrates that it is important to distinguish between surges that end in stops from those that end in normal episodes.

This paper highlights that surges transition either to stops or to normal episodes of gross capital inflows. Given that surges can either end in stops or normal episodes, it then follows that there are two types of surges. Understanding surge transitions and differentiating between two types of surges is important for both policy and economics literature. On policy, knowing where surges could end and differentiating between two types of surges will help design appropriate policy responses in managing surges in gross capital inflows. For instance, several emerging economies have imposed

\footnotetext{
${ }^{1}$ See Benigno et al. (2015), Calvo (1998), Ghosh et al. (2014), Ghosh et al. (2016), and Reinhart and Reinhart, (2009).

2 This paper follows the terminology of Forbes and Warnock (2012a, 2012b). "Surges" refer to more than usual increase in gross capital inflows, while "stops" pertain to more than usual decrease in gross capital inflows. Both stops and surges are defined as extreme episodes of gross capital inflows and are foreign-driven.
} 
capital controls in 2010 to 2011 to temper currency appreciation and asset price inflation. But imposing capital controls conditional on a surge episode may or may not be warranted depending on whether the conditions that give rise for surge to transition to a stop episode are present. If global and domestic factors relevant for surges to end in stops are absent, then imposing capital controls is uncalled for as the huge foreign capital inflows would not necessary lead to sharp reversal of capital inflows.

On literature, previous studies on capital flows emphasize that surges lead to stops. However, they are quiet on that fact that most surges do not lead to stops. ${ }^{3}$ Differentiating between transitions of surges to stops from surges to normal episodes and identifying two types of surges allow for a greater understanding of the patterns, volatilities and dynamics of capital flows. This study contributes to the literature on surges of capital inflows by stressing the point that not all surges are alike as the global and domestic factors correlated with their transition to another episode as well as the amount of gross inflows during surge types are different.

This paper sets out several tasks and addresses several questions. First, we focus on what factors correlate with the transition of surges to stop episodes. Specifically, we ask what factors are correlated with the occurrence of surges ending in stops. Policy makers are more concerned with surges that end in huge foreign capital outflow as they usually coincide with output contractions and crises. Knowing which factors are relevant in such occurrence of transition would have important policy implications.

Second, we look at factors associated with the magnitude of gross capital inflows for surges ending in stops and for surges ending in normal episodes. In essence, we are identifying and differentiating two types of surges in relation to their transition to either stop or normal episodes. In this regard, we ask three questions. First, are surges different from other episodes of gross capital inflows such as stops and normal episodes? Ghosh et al. (2014) have pointed out that surges are indeed different. We do the same exercise in the context of various episodes of gross capital inflows. Second, if surges are different from other episodes, are surges ending in normal episodes different from those leading to stops? Addressing this question allows us to differentiate these two types of surges. Third, do the two types of surges behave differently for advanced and emerging economies? Most studies on surges focus on emerging countries. The rationale for this is that emerging economies are more vulnerable to surges that end in stops. But the global financial crisis of 2008-09 has shown that advanced economies are vulnerable to such transitions as well.

In order to address these questions, we proceed as follows. First, using quarterly data on gross capital inflows from 1982Q4 to 2014Q4 for 55 advanced and emerging economies, we identify for each quarter whether an economy is in a stop, normal, or surge episode following the approach of Forbes and Warnock (2012a). Second, we differentiate between surges that end in stops from those that end in normal episodes. Third, after identifying where surges end, we test the significance of global and domestic factors on the likelihood of experiencing surges that end in stops. Fourth, to establish that surges ending in stops are different from surges ending in normal episode, we test the significance of global and domestic factors conditional on being in a surge type to show which factors are significantly correlated with the magnitude of gross capital inflows for that surge type.

\footnotetext{
${ }^{3}$ Ghosh et al. (2016) have also highlight that not all surges end painfully, but their focus is on financial crises and output contraction, whereas this paper looks at huge foreign capital outflows following surges. In essence, this study is related more to the transition between surges to stops and surges to normal episodes. Benigno et al. (2015) look into capital flow reversals following a surge episode of net capital inflows but they focus more on the sectoral allocation effects. Sula (2010) finds significant evidence that surges increase the probability of stops but the author does not differentiate between surges that end in stop episodes from those that do not. Kim et al. (2014) argue that 60 percent of surges end in stops, which is considerably large.
} 
The results show that the higher likelihood of surges ending in stops is significantly correlated with lower global risk aversion and with higher domestic output gap. This holds true for both advanced and emerging economies. However, the results indicate that the higher likelihood of surges ending in stops is significantly related with higher global growth for emerging economies, but with lower global growth for advanced economies. For emerging economies, higher domestic credit is correlated with higher occurrence of having surges ending in stops. In terms of differentiating between two types of surges, the estimates indicate that surges ending in stops are different from surges ending in normal episodes as both global and domestic factors correlated with the magnitude of capital inflows in these two types of surges vary. For instance, although global interest rate, global risk aversion and domestic credit are significant for both types of surges, larger gross capital inflows are significantly correlated with higher global commodity prices for surges ending in stops, but with lower global commodity prices for surges ending in normal episodes. Similarly, larger gross capital inflows are significantly associated with higher domestic output gap and capital account openness for surges ending in stops but not for surges ending in normal episodes. These results suggest that the transition from surges to stops or to normal episodes and the size of foreign-driven capital inflows of surge types are correlated with both global and domestic factors.

This paper proceeds as follows. Section 2 provides the conceptual framework and literature review. Section 3 discusses the empirical specification. Section 4 identifies episodes of gross capital inflows and differentiates between two types of surges. Stylized facts are also presented. Section 5 presents the baseline and sensitivity results, while Section 6 concludes.

\section{Conceptual Framework}

\subsection{Capital Flows "Push" and "Pull" Framework}

The economics literature on capital flows is vast. A key area of research in this field pertains to the drivers of capital flows across countries. In this area, the overarching theme is which factors matter most for capital flows. These factors are broadly categorized as "push" factors which are external to an economy, and domestic "pull" factors pertaining to domestic macroeconomic fundamentals. The prevailing consensus in the literature points to the relevance of both factors. For instance, Calvo et al. $(1993,1996)$ and Fernandez-Arias (1996) find global factors, such as interest rates related to business cycles in advanced economies, matter more than domestic factors. In contrast, Chuhan et al. (1998) argue more for domestic factors, such as prospective returns on domestic investment. But most studies find the relevance of both factors not only for the size but also for the volatilities of total and components of capital flows. ${ }^{4}$

A narrower branch of literature on capital flows looks at the "push" and "pull" factors in the context of unusually large foreign capital inflows or outflows, known as either "surges" or "stops" which are broadly grouped as extreme episodes. Understanding the determinants and consequences of these extreme episodes of capital flows in the context of global and domestic factors has become important in the literature as it has significant policy implications. For example, if global factors are more relevant during episodes of large foreign capital outflows than domestic factors, then it implies that policy makers have little influence over such huge foreign outflows. The same goes for large foreign capital inflows. But if domestic factors are more pertinent, then domestic policy makers have more control over the adverse consequences of stops and surges.

In this regard, several studies look into the relevance of global and domestic factors during extreme episodes of capital flows. The findings indicate that the high occurrence of "stops" relates to lower domestic growth, more financially open economies, large dollarization of domestic liabilities,

\footnotetext{
${ }^{4}$ See Koepke (2015) for a comprehensive review on the literature of capital flows under the push and pull framework.
} 
dependence on commodity exports, low global growth, high global risk, foreign-driven, huge banking inflows, large exchange rate depreciation, and contagion effects. In contrast, economies more open to trade are less vulnerable to "stops" as foreign investors associate trade openness with lower probability of debt default, while those with more stable economies also experience less "stops". ${ }^{5}$

For "surges", low global interest rates that make debt payment and access to international funding easier, global risk aversion, and business cycles in advanced economies are the relevant global factors. Policy reforms, trade and financial openness, sound macroeconomic policy, growth shocks, external financing needs, and exchange rate regime are the significant domestic factors. In addition, contagion factor is also significant. ${ }^{6}$

\section{2 "Push" and "Pull” Framework under Capital Flow Episode Transitions}

Existing studies on surges also highlight that changes in global and domestic factors can cause surges to end in economic downturns and crises. There are two main channels in which surges can end painfully in output collapse and crises. First, low global interest rate, strong growth in advanced countries, greater financial openness and policy reforms in host countries can trigger huge foreign capital inflows. This leads to higher consumption of non-tradable goods which raises relative prices causing real exchange rate appreciation. This causes sectoral reallocation, output decline, crises and even reversal of capital inflows (Benigno et al. 2015; Calvo et al. 1993, and 1996; Ghosh et al., 2016; and Reinhart and Reinhart, 2009). The second channel is through banking sector. Low global interest rates and higher investor risk appetite can trigger surges in capital flows and facilitate domestic credit booms. As domestic bank lending increases, it raises the likelihood of banking and currency crises since lower borrowing costs exacerbate moral hazard problem, riskier investments leading to productivity decline, and currency mismatches. These lead to crises as argued by Caballero (2014), Gorton and Ordoñez (2016), Ghosh et al. (2016), and Magud et al. (2014).

There are several papers that look into the transition from surges to stops such as those from Accominotti and Eichengreen (2013), Benigno et al. (2015), Kim et al. (2014), Reinhart and Reinhart (2009), and Sula (2010). From a historical narrative, Accominotti and Eichengreen (2013) find that similar to surges that preceded stops during the global financial crisis of 2007-08, advanced countries also underwent a similar progression in the inter-war period of 1919 to 1932. Benigno et al. (2015) and Sula (2010) argue that surges increase the probability of stops. However, Benigno et al. (2015) do not find significant evidence between surges and the probability of experiencing net capital flow reversal. ${ }^{7}$ In contrast, Sula (2010) finds that surges increase the probability of experiencing stops especially when foreign capital inflows are driven by private loans. The probability of experiencing stops also increases when a country is running a current account deficit and has an appreciating real exchange rate. Kim et al. (2014) show that, on average, 60 percent of surges end in stops. ${ }^{8}$ Reinhart and Reinhart (2009) indicate that capital bonanza episodes "end, more often than not, with an abrupt reversal or 'sudden stop' a la Calvo (1998)".

These studies highlight the transition from surge to stop episodes. But little is known or mentioned about surges that end in normal episodes. It should be pointed out that not all surges actually lead

\footnotetext{
${ }^{5}$ Refer to the studies of Calderon and Kubota (2013), Calvo et al. (2008), Cavallo and Frankel (2008), Forbes and Warnock (2012a), Levchenko and Mauro (2007), Milesi-Ferretti and Tille (2011), and Rothenberg and Warnock (2011).

${ }^{6}$ See the papers of Caballero (2014), Calvo et al. (1993 and 1996), Forbes and Warnock (2012a and 2012b), Ghosh et al. (2014), Magud et al. (2014), and Reinhart and Reinhart (2009).

${ }^{7}$ Benigno et al. (2015) define reversal in capital flows as negative net capital inflows using current account and foreign reserve data.

8 Kim et al. (2014) use different methods in identifying surges which is mainly deviation from some benchmark measure but define "stops" as reduction in gross inflows by 3 percent of GDP. In short, they use inconsistent definitions of surges and stops. The authors also use annual data for emerging countries. Using annual data to capture episodes of capital flows could lead to missed episodes such as those that last for less than a year like those which lasted for only two quarters. Furthermore, the authors do not specify their underlying data source whether Financial Accounts or the Current Account of the Balance of Payment Statistics.
} 
to stops as it is possible that countries experiencing surges could allow for greater domestic adjustments, or global factors might not necessarily deteriorate substantially which might not necessary entail foreign capital outflows. Furthermore, no study has differentiated between two types of surges. One that ends in stops and the other that ends in normal episodes. It is this gap in the literature which this paper addresses.

This study is related to the literature on surges in capital inflows in line with Forbes and Warnock (2012a) and Ghosh et al. (2014). However, unlike both studies, this paper specifically identifies two types of surges in the context of "push" and "pull" framework. Unlike Ghosh et al. (2016) who focus on the impact of surges on output and crises, this paper deals with the transitions between episode types of capital inflows. In contrast to Benigno et al. (2015) and Sula (2010), who look into the significance of surges and other factors on the likelihood of stops, this paper focuses on global and domestic factors correlated with the likelihood of having surges ending in stops conditional on being in a surge episode. Unlike the paper of Kim et al. (2014), this paper uses consistent identification of capital inflow episodes, following Forbes and Warnock (2012a), and looks at factors correlated with the occurrence of surges ending in stops.

\section{Empirical Specification}

The main objectives of this paper are to identify different types of surges and understand surge transitions. To this end, we highlight the role of global and domestic factors in the literature on capital inflows that are correlated with the occurrence of surges ending in stop episodes and with the magnitude of gross capital inflows for the two types of surges. We also look into whether the significance of global and domestic factors hold when we split the sample between advanced and emerging economies. We proceed as follows.

First, using our identified types of surges, we test the significance of global and domestic factors for the occurrence of surges ending in stops conditional on being in a surge episode. This pertains to the relevance of factors on surge transitions. Our first empirical specification is given by

$$
P\left(s_{i, t}=1\right)=g_{t}^{\prime} \beta_{1}+d_{i, t}^{\prime} \gamma_{1}+\varepsilon_{i, t}
$$

where $s_{i, t}$ is a dummy variable that takes a value of 1 if the a surge episode ends in a stop episode, and 0 if a surge episode ends in a normal episode, for country $i$ in quarter $t$ conditional on being in a surge episode. $g_{t}$ and $d_{i, t}$ are global and domestic factors, respectively, for country $i$ in quarter $t$ conditional on being in surge. $\varepsilon_{i, t}$ refers to the error term.

Equation (1) is estimated using a probit model with robust standard errors for 55 economies from 1982Q4 to 2014Q4. We do not use lagged values of the regressors to address potential endogeneity. ${ }^{9}$ Our reason for this is that we are estimating the outcome variable (surges leading to stops) on the contemporaneous values of the regressors in that surge episode. In effect, we are estimating the dependent variable on its lagged values. This reduces potential endogeneity. Nonetheless, we interpret the results as correlations instead of causation. We report conditional marginal effects for all variables at their mean values.

Second, using our identified episodes of gross capital inflows (stops, normal, and surges), we test the significance of global and domestic factors on the magnitude of gross capital inflows conditional on

\footnotetext{
${ }^{9}$ We conducted a sensitivity analysis using lagged values as regressors. The baseline results hold.
} 
being in one of these episodes. We highlight that capital flows behave differently across different types of episodes. Ghosh et al. (2014) use the same approach to establish that net capital inflows during surges are different from other episodes. Next, we focus on surges and then split these between surges that end in normal episodes and those that end in stops. This will show that gross capital inflows during surges that end in normal episodes are different from those that end in stops. In effect, we are distinguishing between the size of gross capital flows during the two types of surges given global and domestic factors. Finally, we test whether these two surges exist in both advanced and emerging economies. Recent papers on surges, including those from Ghosh et al. (2014) and Sula (2010), focus on emerging economies. But to clearly point out that these two surges exist both in advanced and emerging economies, we split our sample. Our second empirical specification is as follows

$$
K_{i, t}=g_{t}^{\prime} \beta_{1}+d_{i, t}^{\prime} \gamma_{1}+\varepsilon_{i, t}
$$

where $K_{i, t}$ stands for gross capital inflows as percent of annual GDP for country $i$ in quarter $t$ conditional on being in a particular episode or surge type. $g_{t}^{\prime}$ are global factors in quarter $t$ conditional on being in a particular episode or surge type; and $d_{i, t}^{\prime}$ are domestic factors for country $i$ in quarter $t$ conditional on being in a particular episode or surge. $\varepsilon_{i, t}$ refers to the error term.

Equation (2) is estimated using pooled OLS with robust standard errors for 55 economies from $1982 \mathrm{Q} 4$ to $2014 \mathrm{Q} 4$. We do not include country fixed-effects as we want to test the significance of domestic factors without controlling for other unobserved country characteristics. Including countryfixed effects might cause downward bias on the significance of domestic factors as pointed out by Forbes and Warnock (2012a, 2012b) and Ghosh et al (2014). Given our specifications, we do not use lagged values of the regressors to address potential endogeneity. Our reasoning for this is that we are interested in the significance of domestic and global factors conditional on being in particular type of episode. If we use lagged values, the values for the first quarter in an episode will correspond to the last values in the preceding episode. Thereby, we would not be exclusively accounting for all the values corresponding to a particular episode. ${ }^{10}$ Consequently, we are not claiming causality but rather conditional correlations. Although we are using the same dependent and independent variables, we do not run seemingly unrelated regression as we are imposing the condition of being in a particular episode type. Hence, the data points included in each specification are different. Unlike Ghosh et al. (2016), we do not look into the changes in the global and domestic factors as we are interested in which factors are correlated with the occurrence of surges ending stops, and with the magnitude of gross capital inflows for the two types of surges. Using changes could lead to inconsistent results. Consider a case in which a country is in a recession in the pre-surge period and grows significantly during the surge period. The change in growth will be overestimated in this case. Therefore, we look into correlations of current factors with capital inflows during surge episodes.

Given both empirical specifications, we note several points. First, Equation (1) looks into which domestic and global factors are significant for the likelihood of having surges leading to stops. This pertains to the probability of occurrence. Our specification differs from Benigno et al. (2015) and Sula (2010) as both papers use probit model with a dummy variable taking the value of 1 if there is the occurrence of a stop episode or net capital inflow reversal and 0 otherwise. In their specification, a variable for a surge episode is included as a regressor. In Equation (1), the transition from a surge to a stop episode is embodied in the binary variable by itself.

${ }^{10}$ We conduct a sensitivity test using lagged values. The results are consistent with our baseline results. 
Second, Equation (2) aims to show that surges are different from other types of capital inflows, and that there are two types of surges that exists both in advanced and emerging economies. We highlight the difference between these two surges based on the significance of push and pull factors correlated with the magnitude of gross capital inflows. For instance, if a global factor is significant for surges leading to stops and not for surges leading to normal episodes, we say that the global factor significantly increases the size of gross capital inflows for surges leading to stops, and not for surges leading to normal episodes. This way, we differentiate between the two surges. This approach is similar to Ghosh et al. (2014), but the crucial difference is that this paper differentiates two types of surges.

\section{Data and Stylized Facts}

\subsection{Gross Capital Inflows}

Considerable discussion has been made in the literature of capital inflows on how to best capture the determinants and consequences of extreme episodes. Central to any analysis in this research is the choice between using net or gross capital inflows in identifying extreme episodes. Using either net or gross capital inflows sheds light on our understanding of stops and surges. However, the choice between the two has profound implications on how the findings are interpreted. For instance, the use of net capital inflows are preferred when looking at the macroeconomic impacts of surges including those on domestic growth, sectoral reallocation, exchange rate, terms of trade, and current account. But the use of net capital inflows in understanding extreme episodes compounds cross-border investment decisions of both domestic and foreign investors. For example, a country faced with huge foreign investment outflow can mitigate its macroeconomic impact by running down its foreign reserves or retrenching its foreign assets, thereby, having smaller or even positive net capital inflows.

In order to disentangle the decisions of domestic and foreign investors, the use of gross capital inflows is warranted. Differentiating between domestic and foreign capital flows assumes that both types of investors behave differently during periods of high or low financial risks. ${ }^{11}$ During the global financial crisis of 2008-09, domestic investors in advanced economies faced credit constrains and witnessed huge foreign capital outflows, and so they repatriated their foreign assets (Milesi-Ferretti and Tille, 2011). In this case, domestic and foreign investors behave symmetrically. But there are also instances when huge foreign capital outflows are matched by capital flight, thereby domestic investors reinforce the negative impact of foreign capital outflows. In this case, the actions of both foreign and domestic investors are asymmetric. This clearly illustrates the importance of disentangling capital flows driven by domestic and foreign investors.

To understand which factors are relevant for foreign-driven inflows and their relation to transitions between episodes of capital flows, using gross capital inflows is more appropriate. Specifically, to know how foreign capital inflows respond to changes in global and domestic factors or financial risks during an episode and its subsequent ending to another episode, using gross capital inflows is warranted. ${ }^{12}$ For these reasons, this paper focuses on gross capital inflows.

\footnotetext{
11 Total gross capital outflows must technically include foreign reserves. But considering net capital inflows entails including policy actions in response to capital flow reversals. In this case, net capital inflows are more stable as it considers policy actions to counteract extreme episodes of capital flows.

12 Applying Forbes and Warnock (2012a) method to identify "surges" and "stops" on net capital inflows would lead to different results. For instance, global risk aversion is insignificant for the transition from surges to stops using net inflows. But similar to the findings in this paper, the significance of global and domestic factors varies for the two types of surges.
} 
Aside from the choice between gross and net inflows, another issue in the literature of extreme episodes is how to measure surges. Surges are usually defined to imply more than the usual increase in capital inflows. However, there are various approaches in measuring "more than the usual". Crystallin et al. (2015) provide a survey on the various measures of surges and show that these measures affect the number of surges identified. Common to the six methods they identify and test is their finding that surges have been increasing over time especially using gross capital inflows. The six surge identification method enumerated by Crystallin et al. (2015) can be broadly classified into two. First, surges are periods when capital inflows increase more than the usual based on some deviation from benchmark of what "usual" is. Deviation could refer to one or two standard deviation from benchmark which can either be the historic mean, filtered trend, or magnitude (size relative to GDP) such as those from Balakrishnan et al. (2013), Benigno et al. (2015), Caballero (2014), Forbes and Warnock (2012a and 2012b), IMF (2011), Magud et al. (2014), and Sula (2010). Second, surges are also identified based on some threshold percentile for the entire sample. This is the approach taken by Benigno et al. (2015), Ghosh et al. (2014 and 2016) and Reinhart and Reinhart (2009).

One drawback of the second approach is that in setting the top percentile, episodes of negative capital inflows are included regardless of whether one uses net or gross inflows. Removing those negative inflows would set the cut-off of top percentile for each country even higher especially for those that experience frequent stops. Therefore, there could be some missed episodes. For this reason, this paper applies the first approach. Among the variations in the first approach (deviation from some benchmark), this paper employs Forbes and Warnock (2012a and 2012b) approach in identifying extreme episodes. ${ }^{13}$ Distinct from Forbes and Warnock (2012a and 2012b) method is that they impose a two standard deviation from historic rolling mean rule on top of the one standard deviation criteria. This ensures that the identified extreme episodes have substantial disruptive impact on the economy and that the identified increase or decrease is truly large relative to a country's historic mean.

To restate, Forbes and Warnock (2012a and 2012b) define a surge as an episode where gross capital inflows increase more than one standard deviation above its historic mean provided that: (i) it reaches at least two standard deviation above at some point within that episode; (ii) the entire episode lasts more than one quarter; and (iii) there are at least four years of data to calculate the historic mean. Specifically, we let $C_{t}$ be the four-quarter moving sum of gross capital inflows (GINFLOW) and derive annual year-on-year changes in $C_{t}$ :

$$
\begin{gathered}
C_{t}=\operatorname{GINFLOW}_{t}+\text { GINFLOW }_{t-1}+\text { GINFLOW }_{t-2}+\text { GINFLOW }_{t-3}, \\
\Delta C_{t}=C_{t}-C_{t-4},
\end{gathered}
$$

Rolling average and standard deviations of $\Delta C_{t}$ are computed over the last 20 quarters or 5 years. ${ }^{14} \mathrm{~A}$ surge episode is defined starting the first month $t$ that $\Delta C_{t}$ increases more than one standard deviation above the historic rolling mean. ${ }^{15}$ But in order for the entire episode to qualify as surge there must be at least one quarter $t$ when $\Delta C_{t}$ increases at least two standard deviation above its

\footnotetext{
${ }^{13}$ Ghosh et al. (2014) considered the presence of global surges in identifying individual country surge episodes. However, this reinforces the importance of global factors and does not account for individual country surge experiences. For instance, consider a country which opened up to foreign investments and offers high returns at a time of global slowdown. Since there is no global surge, such episodes will not be included in Ghosh et al. (2014) but will be included in Forbes and Warnock (2012a). Given such cases, we use Forbes and Warnock's (2012a) approach in identifying extreme episodes.

${ }^{14}$ To maximize available data, a four-year rolling mean and standard deviation is used at the start of the series, following the approach of Forbes and Warnock (2012a and 2012b).

${ }^{15}$ The value for current quarter $(\mathrm{t})$ is excluded in computing for the historic mean and standard deviation.
} 
historic mean. A stop is defined using a similar approach but pertains to the opposite direction. We define normal episode as quarters without extreme episodes.

Our primary data source for quarterly gross capital inflows is the Balance of Payments Statistics from the International Monetary Fund's (IMF) International Financial Statistics (IFS). Data are accessed from CEIC Database. We define gross capital inflows to include foreign direct investment liabilities, portfolio investment liabilities and other investment liabilities. The primary period coverage is from 197001 to 201404 for 55 advanced and emerging economies. However, we decided to use identified episodes starting $1982 \mathrm{Q} 4$ as most of our regressors have available data around $1982 .{ }^{16}$

To illustrate the method of identifying episodes of gross capital inflows, Figure 1 applies the method for Brazil. The illustrated pattern shows striking resemblance to Forbes and Warnock's (2012a) Figure 2 for Brazil. ${ }^{17}$ Given our identified episodes for gross capital inflows, several distinctions are noted. First, there are marked differences in the identified surges accounting for the fact that Forbes and Warnock (2012a) used net errors and omissions to fill in missing data. In this paper, no attempt to clean the data has been made so as to rely primarily on the classified financial transactions in the Balance of Payments Financial Accounts. Second, the starting and ending quarters of identified surges can be different from Forbes and Warnock (2012a) as we reclassified extreme episodes separated by one quarter of normal episode to the succeeding extreme episode. For example, some countries in 2008Q3 have normal episode between a surge episode in 2008Q2 and stop episode in 2008Q4. We then reclassify the normal episode identified in 2008Q3 as stop episode to account for the fact that the global and domestic conditions prevailing during that quarter actually corresponds to conditions in the stop episode. Although there are slight differences between this paper and Forbes and Warnock (2012a), the identified extreme episodes in this paper are in line with their observed patterns.

\subsection{Surge Types}

One of the key points argued in this paper is that not all surges end in stops. In fact, most surges end in normal episodes. Although most studies on surges do not highlight the importance of these two surges, there are existing studies that stress this importance in the context of hard and soft landings. Both Benigno et al. (2015) and Ghosh et al. (2015) also point out that not all surges end painfully as some surges end safely. Benigno et al. (2015) distinguish between surges that end in reversals of net capital inflows from those that end in sudden stops following Calvo et al. (2008). However, they use data on net capital inflows, which accounts for the positions taken by domestic and foreign investors, and the surge definition of Caballero (2014). Ghosh et al. (2016) differentiate two surges in which one ends in financial crises or output contractions and the other ends safely but they used net capital inflows and the approach of Reinhart and Reinhart (2009) in identifying surges.

This paper differs from Benigno et al. (2015) and Ghosh et al. (2015) in identifying types of surges. Applying the episode identification approach of Forbes and Warnock (2012a) for gross capital inflows, two types of surges are identified. One leads to normal episodes and the other leads to stop episodes. Crucial to this distinction is the cut-off period when one could say that a surge ended safely or badly. Given the use of quarterly data, the obvious cut-off period would be four quarters or one year to account for policy time lags and the fact that four quarters might be sufficient for global and domestic factors to change substantially. ${ }^{18}$

\footnotetext{
${ }^{16}$ See Appendix 1 for a discussion on capital flows data.

${ }^{17}$ Refer to Figure 2 page 239 of Forbes and Warnock (2012a). We note that the underlying data is stationary.

18 In our sensitivity test, we find that extending the cut-off to eight quarters or two years does not alter our baseline results. But we note some changes in the significance of global factors.
} 
To identify the two types of surge, we use the following criteria. We identify a surge episode ending in normal episode if the four subsequent quarters following the last surge quarter are quarters of normal episode. On the other hand, we identify a surge episode ending in a stop episode if a stop episode begins in less than four quarters following the last surge quarter.

Tables 1 and 2 show the summary statistics of identified surges classified into either surges ending in normal episodes or surges ending in stops for advanced and emerging economies. ${ }^{19}$ Several observations are noted. First, the magnitude of gross capital inflows for surges ending in stops is larger compared to the size of gross capital inflows for surges ending in normal episodes (Table 1). This pattern holds true for all economies and for the split between advanced and emerging economies. This implies that, on average, gross inflows for surges leading to stops are larger than those leading to normal episodes. Hence, its disruptive potential to economies is greater. Second, most surges end in normal episodes for both advanced and emerging economies (Table 2). Specifically, around 60 percent of surges end in normal episodes while 40 percent end in stops. ${ }^{20}$ This is true for both advanced and emerging economies. Third, extending the cut-off to eight quarters, around half of all surges still end in normal episodes (Table 2). Therefore, there is no clear indication that most surges end in stops even after using two years as the cut-off point.

Figures 2 to 4 trace the evolution of types of surges through time for all economies (Figure 2), advanced economies (Figure 3 ) and emerging economies (Figure 4). Several findings are noted. First, there is unprecedented number of surges ending in stops in the run up to the global financial crisis of 2008-09. In fact, most surges that occurred around the end of 2005 ended in stops. The same pattern holds when we split the sample between advanced and emerging economies (Figures 3 and 4). Second, there are periods when surges happen frequently or rarely. For instance, in the 1980s most surges happened in advanced economies, while in the 1990s most surges occurred in emerging economies. Third, few surges occurred around 2001 and 2009 due to the global cyclical downturn related to the slowdown in the US economy in 2001 and during the Great Recession of 2008-09, respectively. Fourth, most surges in emerging economies in the post-global financial crisis period ended in normal episodes, although some countries like Brazil, Korea, Taiwan and Thailand imposed capital controls. These stylized facts show that there are two types of surges: one ending in normal episodes, and the other ending in stops. Importantly, most surges end in normal episodes.

\subsection{Global and Domestic Factors}

For Equation (2), we use gross capital inflows as percent of annual GDP as the dependent variable. Quarterly gross inflows are scaled relative to the annual GDP to indicate the size of inflows relative to the size of the economy. Data for gross inflows refer to the sum of foreign direct investment, portfolio investment, and other investment liabilities from the Balance of Payments statistics. The primary data source is the Balance of Payments statistics of the International Monetary Fund. For some countries, we use national sources.

For global factors, we select five indicators common in the literature. We expect that higher global growth, global liquidity, and global commodity prices will trigger surges in capital inflows across countries. In contrast, lower global interest rates will initiate search for higher yields and so capital inflows increase across countries, particularly to emerging countries. The relation between global factors and capital inflows during surges is well documented in the literature (Calvo et al., 1993 and 1996; and Reinhart and Reinhart, 2009). More recent literature points to the importance of global

\footnotetext{
${ }^{19}$ Tables A2 and A3 in Appendix 2 present the identified surges classified into either surges ending in normal episodes or surges ending in stops for advanced and emerging economies, respectively.

${ }^{20}$ This is in stark contrast to Kim et al. (2014) who find that around 60 percent of surges end in stops. The difference could be primarily due to capital flows data, period and country coverage, data frequency, and approach in identifying surge and stop episodes.
} 
risk aversion. Higher global risk aversion is related to stops while lower global risk aversion is related to the occurrence of surges (Forbes and Warnock, 2012a and Ghosh et al. 2014).

Our measure of global growth is quarterly year-on-year change of aggregate real GDP of selected advanced and emerging economies using 2010 constant prices and exchange rate. Global interest rate refers to the quarterly weighted average of long-term interest rates across countries using GDP in constant prices as weights. Both global growth and interest rate are taken from Oxford Economics. Global liquidity growth is the quarterly year-on-year change in aggregate money supply (M2) of selected advanced and emerging economies. Since individual country money supply is expressed in local currency, we convert all values to US dollar using end-of-period exchange rate before aggregating. Money supply and foreign exchange rate are taken from the International Financial Statistics of the IMF. Commodity price index refers to the log value of quarterly unweighted average of global price indexes of agricultural raw materials, metals, energy, and non-fuel commodities taken from the IMF's Primary Commodity Prices Database. We multiply the log value by 10 to make the scale consistent with other indicators. For quarterly global risk aversion variable, we use the Chicago Board Options Exchange volatility index VXO. However, since the data for VXO starts only in 1986Q2, we extend the volatility index to 1982Q4 using estimated standard deviation from a $\operatorname{GARCH}(1,1)$ model of the S\&P futures index.

For domestic factors, we include six measures. Higher output gap, more developed financial system as proxied by market capitalization, per capita income, and greater financial openness are associated with more surges or higher capital inflows (Calvo et al. 1996, Ghosh et al. 2014 and Forbes and Warnock, 2012a). We also include domestic credit to test whether it is associated with higher capital inflows or with the occurrence of surges which increases financial risks through lending boom as pointed out by both Caballero (2014) and Sula (2010). Lastly, we also include real exchange rate appreciation as capital inflows are commonly associated with increasing real exchange rate (Ghosh et al. 2014 and Reinhart and Reinhart, 2009).

Our measure of output gap refers to the deviation of quarterly real GDP from its potential output. We use real GDP in local currency and employ Hodrick-Prescott filter to derive potential output. We source our quarterly real GDP data from Oxford Economics. ${ }^{21}$ Market capitalization refers to the total capitalization of listed companies as percent of nominal GDP. Our primary data sources are World Bank's World Development Indicators and national sources. We convert annual series to quarterly series using linear interpolation. Domestic credit refers to financial resources provided to the private sector as percentage of nominal GDP. Annual data sourced from World Bank's Global Financial Development Dataset are converted to quarterly series through linear interpolation. Capital account openness refers to Chinn-Ito standardized index (Chinn and Ito, 2006). We scale the standardized index to 100 and convert the annual series to quarterly series by repeating the annual values. ${ }^{22}$ Per capita income is the log value of real GDP per capita in constant US\$ prices. We scale the log value by 10 to make the values consistent with other indicators. Data are sourced from Oxford Economics and IMF's World Economic Outlook Database. Finally, our real exchange rate appreciation refers to quarterly year-on-year growth of real effective exchange rate index taken from Bank for International Settlements, International Monetary Fund, and national central banks.

Table 3 presents the average values of all variables during surges. Several observations are noted. First, on average, gross capital inflows are larger for advanced than emerging countries. Second,

\footnotetext{
${ }^{21}$ For some countries with unavailable quarterly data, we use the annual values and then convert to quarterly series using quadratic match sum approach. For most countries, quarterly real GDP in local currency are seasonally adjusted. For those that are not, the series are adjusted using Census $\mathrm{X}-12$ method.

22 Since the latest Chinn-Ito index is available until end-2013, we use 2013 values for our 2014 sample. Data for Taiwan is proxied by data for Korea as the level of de facto financial integration between these two countries are the closets among the countries in the region.
} 
global interest rate is lower for emerging economies during surges, compared to advanced economies. Third, domestic credit during surges in advanced countries tends to be twice as large as that for emerging economies. Lastly, real appreciation is higher in emerging economies during surges compared to advanced economies. This suggests greater exchange rate adjustment in emerging economies during surges.

\section{Empirical Analysis}

\subsection{Baseline Results}

To test the significance of global and domestic factors related to the transition of surges to stops, we run Equation (1) using probit estimation. Table 4 presents the marginal effects on the likelihood of experiencing surges leading to a stop episode conditional on being in a surge episode. The coefficients are the marginal effects at the given mean of each regressor. We note several findings.

For all economies, we find that lower global risk aversion and higher domestic output gap are significantly correlated with higher likelihood of surges leading to stops. Given its negative sign, a one unit decrease in global risk aversion is significantly correlated with a higher likelihood of surges ending in stops by around 1 percent, when all factors are held constant at their mean values. This indicates that among global factors, it is global risk aversion that matters most for the transitions of economies from surge to stop episodes. In contrast, a one unit increase in domestic output gap is significantly associated with higher likelihood of surges leading to stops by around 9 percent, when all factors are at their mean values. This indicates that, conditional on being in a surge episode, an overheating economy has significantly higher likelihood of experiencing a surge ending in a stop.

Although global risk aversion and domestic output gap are significant for both advanced and emerging economies, we find that there are differences between the two country groups as the global and domestic factors significant in explaining the variation among them vary. For instance, higher global growth is significantly correlated with lower likelihood of a surge ending in a stop for advanced economies, but with higher likelihood of a surge ending in a stop for emerging economies. A possible explanation for this is when global growth is strong, cross-border investments increase for both advanced and emerging economies. However, unlike advanced economies, emerging economies may have lower ability to absorb foreign capital given their level of financial development. Hence, large foreign capital inflows can have more destabilizing impact on the economy, which increases the possibility of experiencing foreign capital outflows.

For emerging economies, the estimates show that higher domestic credit is significantly associated with higher likelihood of having a surge end in a stop. Specifically, a one unit increase in domestic credit is significantly correlated with a higher likelihood of experiencing a surge leading to a stop episode by around 0.3 percent, when all factors are held constant at their mean values. This result is consistent with the credit channel of surge to stop narrative of capital inflows, particularly for emerging economies as pointed by Caballero (2014), Calvo (1998), Reinhart and Reinhart (2009), and Sula (2010). However, domestic credit is insignificant for advanced economies, which runs contrary to the experience of advanced economies during the global financial crisis of 2008-09, perhaps because there are more emerging economies in the sample or the recent financial crisis is an exception to overall trend of surges in advanced economies. The estimates also indicate that higher per capita income is significantly related to lower likelihood of having a surge ending in a stop for emerging economies, but not for advanced economies. In contrast, appreciation of the real exchange rate is significantly correlated with higher likelihood of having a surge ending in a stop for advanced economies but not for emerging economies. 
Table 5 presents the results for the magnitude of gross capital inflows conditional on being in various episodes of gross inflows. Column 1 of Table 5 shows the results for the size of gross inflows during stops, Column 2 for normal episodes, and Column 3 for surges. The estimates show that one episode type is different from another as the significance of global and domestic factors differ. For instance, global interest rate and domestic output gap are significant across episode types. But global risk aversion is significant for both stops and surges, but not for normal episodes. There are also factors distinct to surge episodes. Global liquidity and market capitalization are significantly correlated with higher gross capital inflows during stop and normal episodes, but not during surge episodes. In contrast, domestic credit is significantly correlated with higher capital inflows during surges but not during stop and normal episodes. Specifically, a one percent of GDP increase in domestic credit is significantly associated with higher gross capital inflows during surges by around 0.06 percent of GDP. Taken together, these findings indicate that surges are different from stops and normal episodes, consistent with Ghosh et al. (2014), as both global and domestic factors significant in explaining the variation in the size of gross capital inflows during surges are different from those for stop and normal episodes.

Knowing that the factors related to the size of gross inflows are different for surges, we look at whether the global and domestic factors related to the magnitude of gross inflows during surges differ when surges end in normal episodes or when surges end in stops. Table 6 presents the estimates on the magnitude of gross capital inflows conditional on being in two types of surges. Column 1 in Table 6 is the same as Column 3 of Table 5. Column 2 shows the estimates for surges leading to normal episodes, and Column 3 shows the estimates for surges leading to stops. ${ }^{23}$

The results show that common to both surge types, lower global interest rate and lower global risk aversion are significantly correlated with higher gross capital inflows, while higher domestic credit is significantly associated with higher gross capital inflows for both surges. These results are consistent with earlier papers on surges, including Ghosh et al. (2014). But there are striking differences between the two surges. Domestic output gap and capital account openness are significant for surges ending in stops, but not for surges ending in normal episodes. In contrast, per capita income is significant for surges ending in normal episodes, but not for surges ending in stops. The estimates also indicate that higher commodity prices are significantly associated with smaller gross inflows for surges leading to normal episodes, but significantly larger gross inflows for surges leading to stops. This finding is consistent with Ghosh et al. (2014) and Reinhart and Reinhart (2009) where they emphasize the strong relation between commodity price booms and surges. Given that global commodity price is significant for both but has opposite sign highlights the importance of commodity prices in explaining why surges end in stop episodes and, perhaps, even suggest its importance as a predictor for surge transitions. ${ }^{24}$ In summary, Table 6 shows that global and domestic factors related to the magnitude of gross inflows for surges ending in stops are different from those for surges ending in normal episodes. These results provide support for the difference between the two types of surges.

We extend the analysis by looking whether there are differences between advanced and emerging economies. Table 7 is similar to Table 6 but splits the sample into advanced and emerging

\footnotetext{
${ }^{23}$ We disregard interpreting significant negative constant terms in all regression tables as it is unlikely for capital flows to have a mean value when both global and domestic factors are set to zero.

${ }^{24}$ The relation between capital flow surges and high global commodity prices has been studied in the literature (Reinhart and Reinhart, 2009). The key link between the two is low interest rates. Given a low interest rate setting, investor search for higher returns or yields and one of the asset types they invest in are commodities. This drives global commodity prices higher which then triggers capital inflows to emerging and developing economies that are commodity exporters. Hence, any changes in the global environment that could adversely impact global interest rates or global returns could foster capital inflow reversals to commodity exporting countries. In this case, higher global commodity prices can provide a signal that surges can lead to stops.
} 
economies. Columns (1) to (3) are for advanced economies, while Columns (4) to (6) are for emerging economies.

For advanced economies, although domestic credit is significant for both surges, there are clear differences between the two types of surges. Lower global interest rate is significantly associated with higher gross capital inflows for surges ending in normal episodes but not for surges ending in stops. In contrast, lower global risk aversion is significantly correlated with higher gross capital inflows for surges ending in stops but not for surges ending in normal episodes. This suggests global interest rate, which triggers search for yield, is not important in explaining the variation in the size of inflows for surges ending in stops, but what is more relevant in explaining the size of inflows for surges ending in stops is global risk appetite. Taken together, these results suggest global interest rate limits surges while global risk appetite fuels surges in advanced economies but not in emerging economies. Domestic output gap is significant for surges ending in stops but not for surges ending in normal episodes, while per capita income is significant for surges ending in normal episodes but not for surges ending in stops. Market capitalization has opposing impacts. Higher market capitalization is significantly associated with lower gross inflows during surges ending in stops, but with higher capital inflows during surges ending in normal episodes.

For emerging economies, it is striking to note that capital account openness is significant only for emerging countries and its significance holds across surge types. This may relate to the fact that most emerging countries continue to implement liberalization measures or impose restrictions, thereby adding to the variability in the sample. Higher global growth, global liquidity growth, and the real exchange rate appreciation are significantly associated with larger gross capital inflows for surges ending in normal episodes but not for surges ending in stops. On the other hand, larger domestic output gap and higher per capita income are significantly correlated with larger capital inflows for surges ending in stops but not for surges ending in normal episodes. Unlike in the advanced economy sample, lower global risk aversion is significantly related to higher capital inflows for surges ending in normal episodes but not for surges ending in stops. These findings for the advanced and emerging country groups clearly demonstrates the difference between surges that lead to normal episodes and surges that lead to stops hold since the global and domestic factors explaining the magnitude of gross capital inflows in these two types of surges differ.

These baseline results clearly illustrate the varying significance of global and domestic factors in explaining surge transitions as well as the existence of two types of surges. These show that not all surges are alike.

\subsection{Sensitivity Tests}

In order to test whether the results hold under various specifications, we conduct several sensitivity tests. For all sensitivity tests, Columns (1) to (3) pertain to results presented in Columns (1) to (3) of Table 4. Columns (4) to (6) refer to the results presented in Columns (1) to (3) of Table 6. Columns (7) and (8) pertains to the results presented in Columns (1) and (4) of Table 7.

First, to address potential endogeneity, we test our findings using the lagged value of our regressors. But using lagged regressors in our estimation will include values that do not correspond to a given surge episode. Nonetheless, the findings could support our baseline estimates. The results presented in Table 8 are mostly in line with baseline results. However, global growth is no longer significant in Column (2) but is now significant in Columns (4) and (5). Global risk aversion is also no longer significant in Columns (4) to (7). In summary, using lagged values of the regressors support our baseline findings, although we find that global risk aversion losses its significance in 
differentiating between types of surges. The results must be interpreted knowing that lagged values of the regressors, which correspond to the previous episode, are included in the estimation.

Second, to address potential correlation between observations and the error term, we ran regressions using clustered standard errors. When we clustered standard errors by period, we find that the results are broadly similar to the baseline results. But when we cluster by country, the results change. Clustering at the country level allows correlation within each country, but not across countries. This assumption might be too strong as both domestic and global factors would show some degree of correlation due to economic linkages. For this reason, we use robust standard errors and note that the results hold when we use cluster standard errors by period.

Third, given that capital flows and real exchange rates can influence each other, we remove real exchange rate appreciation from our specifications. Calvo et al. (1993) and Reinhart and Reinhart (2009) highlight that a consequence of surges is that it causes real exchange rate appreciation since capital inflows increases domestic spending, which in turn puts upward pressure on the price of nontradable goods. We can then extend our sample to include more surge episodes as data availability for real exchange rate is limited for some countries. The results are presented in Table 9. The estimates are similar to our baseline results. Greater capital account openness, however, is now significantly correlated with lower likelihood of surges ending in stops for emerging economies. Likewise, global growth is no longer significant in Column (8), while global risk aversion is now significant in Column (8). In summary, our baseline results hold when we remove the real exchange rate appreciation, although we do find that for emerging economies some factors have gained or lost significance.

Fourth, we have ignored the impact of regional contagion in our baseline results. It is possible that if most countries in a region are experiencing huge capital inflows, then a country in that region would also experience huge inflows. Such positive regional contagion factors can be a result of greater cross-border financial linkages, investor herding behaviour, and perceived country similarities (Forbes and Warnock, 2012a and Ghosh et al. 2014). We then include a regional contagion dummy variable with a value of 1 when more than half of countries in a region are experiencing surges in that particular period (quarter), and 0 otherwise. The results are presented in Table 10.

The baseline results hold when we include the regional contagion dummy. However, the striking result is that the regional contagion dummy variable comes with a negative sign. Specifically, if at least half of the countries in a region have surges, gross capital inflow tends to be lower by around 3.2 percent of GDP for surges ending in stops in Column (6). This result is consistent with Ghosh et al. (2014). A plausible explanation for this is when other countries in the region experience huge foreign capital inflows, there is a possibility that a country receives relatively less inflows than other countries even if it is in a surge episode, as foreign investors allocate more capital to a country which offers the highest and safest returns. However, regional contagion is insignificant for the occurrence of surges leading to stops in Columns (1) to (3).

Fifth, since we define surges ending in either normal or stop episodes based on at least four quarters of normal episode following the last surge quarter, we extend the criteria to eight quarters to determine whether our findings are sensitive to the definitions as well. The results are presented in Table 11. The key finding is that global growth is no longer significant in Columns (2) and (3). Global liquidity growth is now significant in Columns (2) and (3). In addition, global risk aversion is no longer significant in Column (2). This indicates that changing the window where surges end influences the results only for the global factors and not for domestic factors. This might happen because global factors change faster than domestic factors. In summary, moving from four to eight quarters of 
normal episodes after the last surge quarter yields results showing most global factors either gain or lose significance.

Sixth, since both global liquidity and global interest rate are correlated, it is important to drop either one of them. The rationale for the inclusion of both variables in the baseline regression is in line with previous studies and the divergence between zero-lower bound global interest rate and unconventional monetary policy such as quantitative easing. Between these two variables, we look at the significance of global liquidity instead of global interest rate as it is the provision of liquidity which fosters cross-border investment. Table 12 presents the results removing global interest rate. The results are broadly consistent with the baseline estimates. However, global risk aversion is now insignificant for the advanced and emerging country split in Columns (2) and (3). In addition, global growth is now significant in Columns (4) and (6). Overall, the results hold although some global factors lose significance for the advanced and emerging country split.

Lastly, instead of looking into the level of domestic credit, we consider credit growth. Previous studies including those from Magud et al. (2014) highlight the importance of surges in gross capital inflows on domestic credit growth. ${ }^{25}$ Table 13 presents the results when we replace domestic credit with domestic credit growth. Several points are noted. First, global risk aversion is insignificant in explaining the occurrence of having surges ending in stops for the advanced and emerging economies split. Second, global commodity price is not significantly correlated with the magnitude of surges ending in both normal and stop episodes. A possible implication of these results is that looking into changes does not explain so much of the occurrence and magnitude of gross inflows of the two types of surges. Hence, it would be the levels of global and domestic factors which are more correlated with both occurrence and magnitude of the two surge types.

\section{Concluding Remarks}

This paper sets out to highlight that not all surges are alike. Some surges end in reversal of gross capital inflows. This means that positive gross capital inflows can lead to negative gross capital inflows the following year. This transition from one episode type to another is widely known in the literature. However, there is another type of surge. Some surges end rather gently such that positive gross capital inflows can lead to smaller but still positive capital inflows the following year. This transition from surge to normal episode is not widely known in the literature. It is this gap in the literature that this paper has addressed.

Based on the descriptive statistics and estimation results, this paper finds that the magnitude or size of gross capital inflows during surges is generally large. However, for surges ending in stops, the magnitude of gross capital inflows tends to be even larger than the magnitude of gross inflows for surges ending in normal episodes, suggesting the disruptive potential of large inflows. This distinction is further supported by assessing various factors correlated with the occurrence of surges ending in stops and the magnitude of gross inflows conditional on being in these two types of surges. Our empirical findings clearly illustrate the varying significance of global and domestic factors related to surge transitions and size. Therefore, not all surges are alike.

\footnotetext{
${ }^{25}$ We define domestic credit growth as the year-on-year percentage change on quarterly domestic credit.
} 
Figure 1: Capital Inflows to Brazil

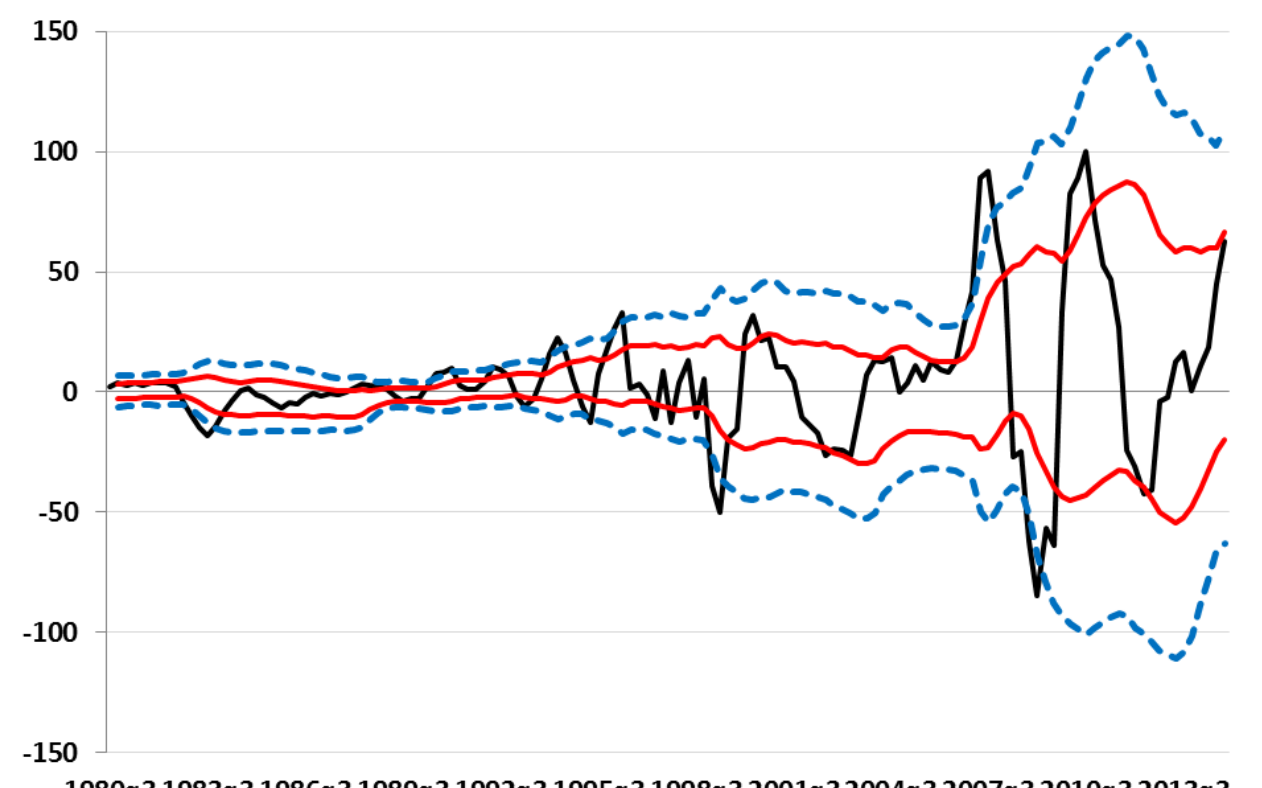

1980q3 1983q3 1986q3 1989q3 1992q3 1995q3 1998q3 2001q32004q3 2007q3 2010q3 2013q3

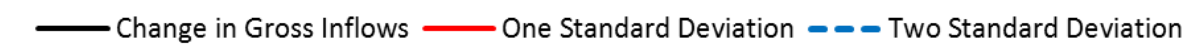

Notes: Values in US\$ billions. Change in gross capital inflows refer to the year-on-year difference of four quarter cumulative gross inflows. Data taken from the Balance of Payment Statistics of the International Monetary Fund. 
Figure 2: Evolution of Surge Types

(All Economies)

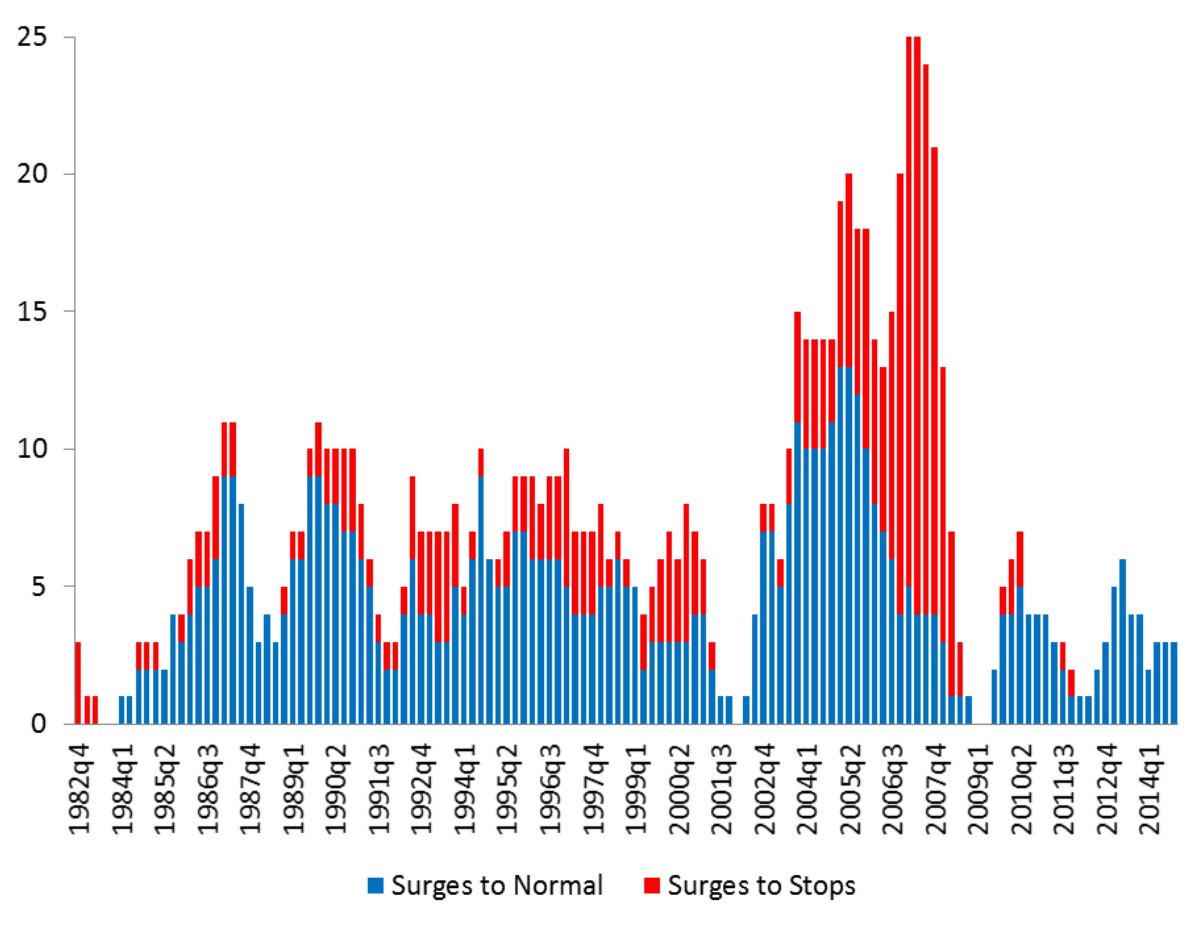

Figure 3: Evolution of Surge Types

(Advanced Economies)

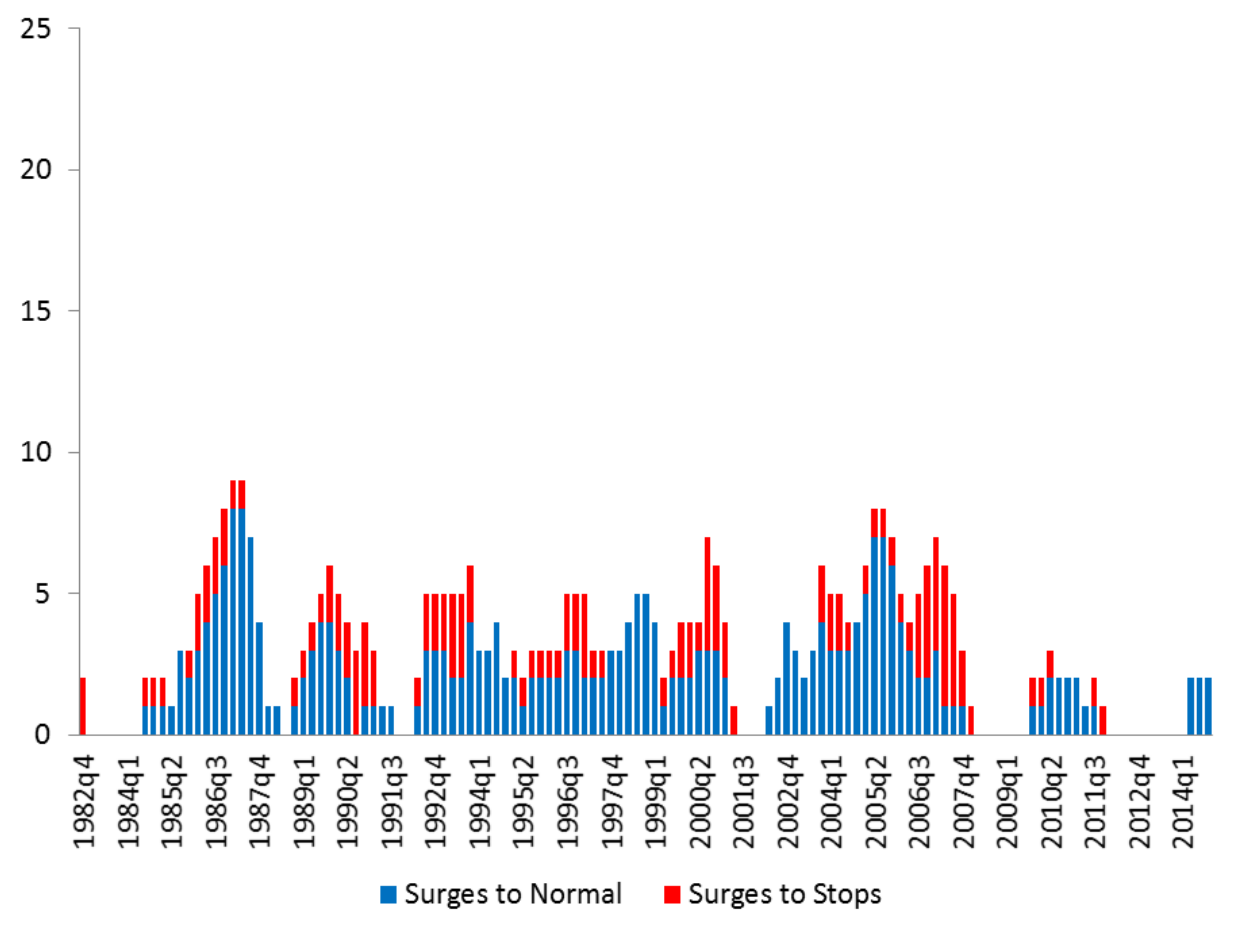


Figure 4: Evolution of Surge Types

(Emerging Economies)

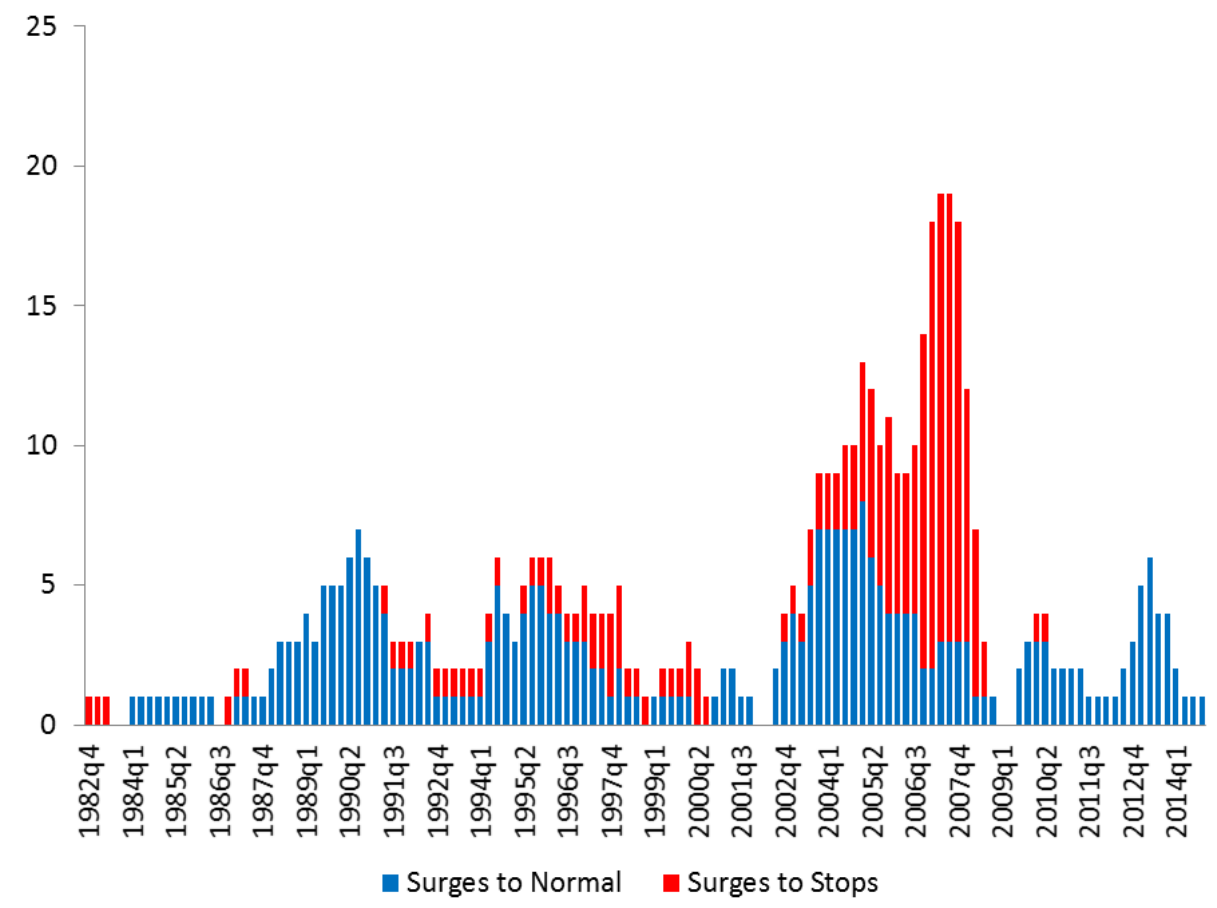

Notes: Values pertain to the number of countries experiencing a particular surge type in a given quarter. Surges are defined following Forbes and Warnock (2012a and 2012b). Advanced and emerging economies sample are shown in Table A1. 
Table 1: Average Gross Capital Inflows for Surge Types

\begin{tabular}{lccc}
\hline & $\begin{array}{c}\text { All } \\
\text { Economies }\end{array}$ & $\begin{array}{c}\text { Advanced } \\
\text { Economies }\end{array}$ & $\begin{array}{c}\text { Emerging } \\
\text { Economies }\end{array}$ \\
\hline Surges Leading to Normal Episodes & 3.61 & 5.42 & 2.10 \\
Surges Leading to Stops & 5.08 & 6.43 & 4.25 \\
\hline Note: Values pertain to the mean of gross capital inflows in percent of nominal GDP for all quarters \\
conditional of being in a particular surge type.
\end{tabular}


Table 2: Summary Statistics of Surge Types

\begin{tabular}{lrccccc}
\hline & $\begin{array}{c}\text { All } \\
\text { Surges }\end{array}$ & $\begin{array}{c}\text { Surges } \\
\text { Leading to } \\
\text { Normal }\end{array}$ & $\begin{array}{c}\text { Surges } \\
\text { Leading to } \\
\text { Stops }\end{array}$ & $\begin{array}{c}\text { Leading to } \\
\text { Normal } \\
\text { (\%) }\end{array}$ & $\begin{array}{c}\text { Leading to } \\
\text { Stops } \\
(\%)\end{array}$ \\
\hline \multicolumn{6}{c}{ At least four normal quarters following the last surge quarter } \\
\hline All Economies & 194 & 121 & 73 & 62.37 & 37.63 \\
Advanced Economies & 92 & 57 & 35 & 61.96 & 38.04 \\
Emerging Economies & 102 & 64 & 38 & 62.75 & 37.25 \\
\hline \multicolumn{6}{c}{ At least eight normal quarters following the last surge quarter } \\
\hline All Economies & 194 & 99 & 95 & 51.03 & 48.97 \\
Advanced Economies & 92 & 46 & 46 & 50.00 & 50.00 \\
Emerging Economies & 102 & 53 & 49 & 51.96 & 48.04 \\
\hline Notes: Surges are defined following Forbes and Warnock (2012a and 2012b). Advanced and emerging \\
economies sample are shown in Table A1.
\end{tabular}


Table 3: Average Values of Key Variables during Surge Types

\begin{tabular}{lrrr}
\hline & \multicolumn{1}{c}{ All } & Advanced & Emerging \\
& Economies & Economies & Economies \\
\hline Gross Inflows & 4.13 & 5.74 & 2.92 \\
Global Growth & 3.32 & 3.26 & 3.37 \\
Global Interest Rate & 9.06 & 10.84 & 7.73 \\
Global Liquidity Growth & 8.30 & 8.57 & 8.09 \\
Commodity Price Index & 45.38 & 44.30 & 46.18 \\
Global Risk Aversion & 18.31 & 19.01 & 17.78 \\
Domestic Output Gap & 0.53 & 0.08 & 0.86 \\
Market Capitalisation & 51.89 & 58.25 & 47.22 \\
Domestic Credit & 69.25 & 94.62 & 50.25 \\
Capital Openness & 64.33 & 83.77 & 49.78 \\
Per Capita Income & 84.17 & 91.32 & 78.81 \\
Real Appreciation & 2.21 & 1.30 & 2.94 \\
\hline
\end{tabular}

Notes: Gross inflows, market capitalization, and domestic credit are in percent of nominal GDP. Global growth, global liquidity growth, and real appreciation are year-on-year quarterly changes in percent. Global interest rate is in percent per annum. Commodity price index and per capita income are in natural log values multiplied by 10 and 100 , respectively. Domestic output gap pertains to the difference of actual and potential output in percent. Capital account openness refers to the standardized Chinn-Ito (2006) index and scaled to 100. Advanced and emerging economies sample are shown in Table A1. 
Table 4: Marginal Effects on the Likelihood of Experiencing Surges Leading to Stops vs. Surges Leading to Normal Episodes

\begin{tabular}{|c|c|c|c|}
\hline & (1) & (2) & (3) \\
\hline VARIABLES & $\begin{array}{c}\text { All } \\
\text { Economies }\end{array}$ & $\begin{array}{l}\text { Advanced } \\
\text { Economies }\end{array}$ & $\begin{array}{l}\text { Emerging } \\
\text { Economies }\end{array}$ \\
\hline Global Growth $_{t}$ & $\begin{array}{c}0.026 \\
(0.022)\end{array}$ & $\begin{array}{l}-0.057^{*} \\
(0.032)\end{array}$ & $\begin{array}{c}0.115^{* * * *} \\
(0.035)\end{array}$ \\
\hline Global Interest Rate $_{\mathrm{t}}$ & $\begin{array}{l}-0.000 \\
(0.002)\end{array}$ & $\begin{array}{l}-0.001 \\
(0.002)\end{array}$ & $\begin{array}{l}-0.001 \\
(0.003)\end{array}$ \\
\hline Global Liquidity Growth $_{\mathrm{t}}$ & $\begin{array}{c}0.001 \\
(0.002)\end{array}$ & $\begin{array}{l}-0.003 \\
(0.003)\end{array}$ & $\begin{array}{c}0.006 \\
(0.004)\end{array}$ \\
\hline 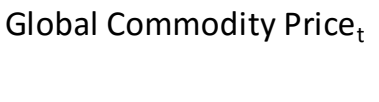 & $\begin{array}{c}0.000 \\
(0.006)\end{array}$ & $\begin{array}{c}0.014 \\
(0.012)\end{array}$ & $\begin{array}{c}0.002 \\
(0.008)\end{array}$ \\
\hline Global Risk Aversion $_{\mathrm{t}}$ & $\begin{array}{c}-0.008^{* *} \\
(0.003)\end{array}$ & $\begin{array}{l}-0.006 * \\
(0.004)\end{array}$ & $\begin{array}{l}-0.009 * \\
(0.005)\end{array}$ \\
\hline Domestic Output Gap $_{\mathrm{i}, \mathrm{t}}$ & $\begin{array}{c}0.085^{* * *} \\
(0.011)\end{array}$ & $\begin{array}{c}0.058 * * * \\
(0.020)\end{array}$ & $\begin{array}{c}0.110 * * * \\
(0.015)\end{array}$ \\
\hline Market Capitalisation $_{\mathrm{i}, \mathrm{t}}$ & $\begin{array}{c}0.001 \\
(0.000)\end{array}$ & $\begin{array}{c}0.001 \\
(0.001)\end{array}$ & $\begin{array}{l}-0.001 \\
(0.001)\end{array}$ \\
\hline Domestic Credit $_{\mathrm{i}, \mathrm{t}}$ & $\begin{array}{c}0.000 \\
(0.001)\end{array}$ & $\begin{array}{l}-0.001 \\
(0.001)\end{array}$ & $\begin{array}{c}0.003^{* * * *} \\
(0.001)\end{array}$ \\
\hline Capital Openness $_{\mathrm{i}, \mathrm{t}}$ & $\begin{array}{l}-0.000 \\
(0.001)\end{array}$ & $\begin{array}{c}0.002 \\
(0.001)\end{array}$ & $\begin{array}{l}-0.001 \\
(0.001)\end{array}$ \\
\hline Per Capita Income $e_{i, t}$ & $\begin{array}{l}-0.003 \\
(0.002)\end{array}$ & $\begin{array}{l}-0.002 \\
(0.005)\end{array}$ & $\begin{array}{c}-0.006 * \\
(0.003)\end{array}$ \\
\hline Real Appreciation ${ }_{i, t}$ & $\begin{array}{c}0.002 \\
(0.002)\end{array}$ & $\begin{array}{l}0.007^{*} \\
(0.004)\end{array}$ & $\begin{array}{c}0.002 \\
(0.003)\end{array}$ \\
\hline Observations & 862 & 381 & 481 \\
\hline Pseudo R-squared & 0.129 & 0.060 & 0.236 \\
\hline
\end{tabular}

Notes: Dependent variable is a dummy variable that takes the value of 1 if surges end in stops and 0 for surges ending in normal episodes. Global growth, global liquidity growth, and real appreciation are year-on-year quarterly changes in percent. Global interest rate is in percent per annum. Commodity price index and per capita income are in natural log values multiplied by 10 and 100, respectively. Domestic output gap pertains to the difference of actual and potential output in percent. Market capitalization and domestic credit are in percent of nominal GDP. Capital account openness refers to the standardized Chinn-Ito (2006) index and scaled to 100. Marginal effects are computed at the means of each variable. Robust standard errors are in parentheses. ${ }^{* * *} p<0.01,{ }^{* *} p<0.05,{ }^{*} p<0.1$. 
Table 5: Magnitude of Gross Capital Inflows Conditional on Various Episode Types

\begin{tabular}{|c|c|c|c|}
\hline & (1) & (2) & (3) \\
\hline VARIABLES & $\begin{array}{c}\text { All } \\
\text { Stops }\end{array}$ & $\begin{array}{c}\text { All } \\
\text { Normal }\end{array}$ & $\begin{array}{c}\text { All } \\
\text { Surges }\end{array}$ \\
\hline Global Growth $_{\mathrm{t}}$ & $\begin{array}{l}-0.084 \\
(0.070)\end{array}$ & $\begin{array}{l}0.129 * * \\
(0.059)\end{array}$ & $\begin{array}{c}0.243 \\
(0.206)\end{array}$ \\
\hline Global Interest Rate $_{t}$ & $\begin{array}{c}-0.024^{* * *} \\
(0.008)\end{array}$ & $\begin{array}{c}-0.024^{* * *} \\
(0.004)\end{array}$ & $\begin{array}{c}-0.057^{* * *} \\
(0.015)\end{array}$ \\
\hline Global Liquidity Growth $_{\mathrm{t}}$ & $\begin{array}{l}0.057^{* *} \\
(0.023)\end{array}$ & $\begin{array}{c}0.020^{*} \\
(0.011)\end{array}$ & $\begin{array}{l}-0.024 \\
(0.028)\end{array}$ \\
\hline 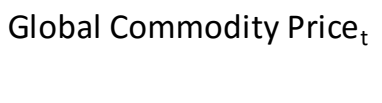 & $\begin{array}{l}-0.065 \\
(0.040)\end{array}$ & $\begin{array}{c}-0.081^{* * *} \\
(0.020)\end{array}$ & $\begin{array}{l}-0.017 \\
(0.068)\end{array}$ \\
\hline Global Risk Aversion $_{\mathrm{t}}$ & $\begin{array}{c}-0.038^{* *} \\
(0.015)\end{array}$ & $\begin{array}{l}-0.011 \\
(0.010)\end{array}$ & $\begin{array}{c}-0.088^{* * *} \\
(0.032)\end{array}$ \\
\hline Domestic Output Gap $_{i, t}$ & $\begin{array}{c}0.121^{* * *} \\
(0.039)\end{array}$ & $\begin{array}{c}0.262^{* * *} \\
(0.050)\end{array}$ & $\begin{array}{c}0.380^{* * *} \\
(0.112)\end{array}$ \\
\hline Market Capitalisation $_{i, t}$ & $\begin{array}{c}0.023^{* * *} \\
(0.006)\end{array}$ & $\begin{array}{c}0.017^{* * *} \\
(0.002)\end{array}$ & $\begin{array}{l}-0.010 \\
(0.007)\end{array}$ \\
\hline Domestic Credit $_{i, t}$ & $\begin{array}{l}-0.010^{*} \\
(0.006)\end{array}$ & $\begin{array}{c}0.004 \\
(0.003)\end{array}$ & $\begin{array}{c}0.045^{* * *} \\
(0.013)\end{array}$ \\
\hline Capital Openness $\mathrm{i}_{\mathrm{i}, \mathrm{t}}$ & $\begin{array}{l}-0.001 \\
(0.008)\end{array}$ & $\begin{array}{c}0.013^{* * *} \\
(0.003)\end{array}$ & $\begin{array}{l}0.018^{*} \\
(0.010)\end{array}$ \\
\hline Per Capita Income $e_{i, t}$ & $\begin{array}{c}0.035 \\
(0.025)\end{array}$ & $\begin{array}{c}0.035^{* * *} \\
(0.010)\end{array}$ & $\begin{array}{c}0.087^{* * *} \\
(0.031)\end{array}$ \\
\hline Real Appreciation ${ }_{i, t}$ & $\begin{array}{c}0.001 \\
(0.012)\end{array}$ & $\begin{array}{c}0.009 \\
(0.007)\end{array}$ & $\begin{array}{c}0.023 \\
(0.025)\end{array}$ \\
\hline Constant & $\begin{array}{c}1.596 \\
(2.983)\end{array}$ & $\begin{array}{c}0.713 \\
(1.134)\end{array}$ & $\begin{array}{l}-4.867 \\
(3.909)\end{array}$ \\
\hline Observations & 783 & 3,885 & 862 \\
\hline R-squared & 0.074 & 0.107 & 0.205 \\
\hline
\end{tabular}

Notes: Dependent variable is gross capital inflows in percent of nominal GDP, conditional on being in a given episode type. Global growth, global liquidity growth, and real appreciation are year-on-year quarterly changes in percent. Global interest rate is in percent per annum. Commodity price index and per capita income are in natural log values multiplied by 10 and 100 , respectively. Domestic output gap pertains to the difference of actual and potential output in percent. Market capitalization and domestic credit are in percent of nominal GDP. Capital account openness refers to the standardized Chinn-Ito (2006) index and scaled to 100. Robust standard errors are in parentheses. ${ }^{* * *} \mathrm{p}<0.01,{ }^{* *} \mathrm{p}<0.05, *$ $\mathrm{p}<0.1$. 
Table 6: Magnitude of Gross Capital Inflows Conditional on being in Surge Types

\begin{tabular}{|c|c|c|c|}
\hline & (1) & $\begin{array}{c}(2) \\
\text { Surges }\end{array}$ & $\begin{array}{c}\text { (3) } \\
\text { Surges }\end{array}$ \\
\hline VARIABLES & All Surges & $\begin{array}{c}\text { Leading to } \\
\text { Normal }\end{array}$ & $\begin{array}{c}\text { Leading to } \\
\text { Stop }\end{array}$ \\
\hline Global Growth ${ }_{\mathrm{t}}$ & $\begin{array}{c}0.243 \\
(0.206)\end{array}$ & $\begin{array}{c}0.310 \\
(0.275)\end{array}$ & $\begin{array}{l}-0.145 \\
(0.329)\end{array}$ \\
\hline Global Interest Rate $_{\mathrm{t}}$ & $\begin{array}{c}-0.057 * * * \\
(0.015)\end{array}$ & $\begin{array}{c}-0.068 * * * \\
(0.018)\end{array}$ & $\begin{array}{c}-0.040 * \\
(0.021)\end{array}$ \\
\hline Global Liquidity Growth ${ }_{\mathrm{t}}$ & $\begin{array}{l}-0.024 \\
(0.028)\end{array}$ & $\begin{array}{c}-0.065^{*} \\
(0.039)\end{array}$ & $\begin{array}{l}-0.040 \\
(0.040)\end{array}$ \\
\hline Global Commodity Price $_{t}$ & $\begin{array}{c}-0.017 \\
(0.068)\end{array}$ & $\begin{array}{c}-0.178^{*} \\
(0.091)\end{array}$ & $\begin{array}{c}0.263^{* *} \\
(0.123)\end{array}$ \\
\hline Global Risk Aversion $_{\mathrm{t}}$ & $\begin{array}{c}-0.088 * * * \\
(0.032)\end{array}$ & $\begin{array}{c}-0.075^{* *} \\
(0.035)\end{array}$ & $\begin{array}{c}-0.120^{*} \\
(0.069)\end{array}$ \\
\hline Domestic Output Gap ${ }_{i, t}$ & $\begin{array}{c}0.380 * * * \\
(0.112)\end{array}$ & $\begin{array}{c}0.067 \\
(0.170)\end{array}$ & $\begin{array}{c}0.475^{* * *} \\
(0.141)\end{array}$ \\
\hline Market Capitalisation $_{\mathrm{i}, \mathrm{t}}$ & $\begin{array}{l}-0.010 \\
(0.007)\end{array}$ & $\begin{array}{l}-0.007 \\
(0.008)\end{array}$ & $\begin{array}{l}-0.015 \\
(0.012)\end{array}$ \\
\hline Domestic Credit $_{i, t}$ & $\begin{array}{c}0.045^{* * *} \\
(0.013)\end{array}$ & $\begin{array}{c}0.040 * * \\
(0.016)\end{array}$ & $\begin{array}{c}0.056 * * \\
(0.022)\end{array}$ \\
\hline Capital Openness $_{i, t}$ & $\begin{array}{l}0.018 * \\
(0.010)\end{array}$ & $\begin{array}{c}0.008 \\
(0.015)\end{array}$ & $\begin{array}{c}0.030 * * * \\
(0.008)\end{array}$ \\
\hline Per Capita Income ${ }_{i, t}$ & $\begin{array}{c}0.087^{* * *} \\
(0.031)\end{array}$ & $\begin{array}{c}0.110 * * * \\
(0.037)\end{array}$ & $\begin{array}{c}0.037 \\
(0.038)\end{array}$ \\
\hline Real Appreciation $n_{i, t}$ & $\begin{array}{c}0.023 \\
(0.025)\end{array}$ & $\begin{array}{c}0.031 \\
(0.029)\end{array}$ & $\begin{array}{c}0.058 \\
(0.053)\end{array}$ \\
\hline Constant & $\begin{array}{l}-4.867 \\
(3.909)\end{array}$ & $\begin{array}{c}0.978 \\
(4.801)\end{array}$ & $\begin{array}{c}-13.100 * * \\
(6.373)\end{array}$ \\
\hline Observations & 862 & 547 & 315 \\
\hline R-squared & 0.205 & 0.188 & 0.264 \\
\hline
\end{tabular}

Notes: Dependent variable is gross capital inflows in percent of nominal GDP conditional on being in surge types. Global growth, global liquidity growth, and real appreciation are year-on-year quarterly changes in percent. Global interest rate is in percent per annum. Commodity price index and per capita income are in natural log values multiplied by 10 and 100 , respectively. Domestic output gap pertains to the difference of actual and potential output in percent. Market capitalization and domestic credit are in percent of nominal GDP. Capital account openness refers to the standardized Chinn-Ito (2006) index and scaled to 100. Robust standard errors are in parentheses. ${ }^{* * *} p<0.01,{ }^{* *} p<0.05,{ }^{*} p<0.1$. 
Table 7: Magnitude of Gross Capital Inflows Conditional on being in Surge Types, Advanced and Emerging Economies Split

\begin{tabular}{|c|c|c|c|c|c|c|}
\hline VARIABLES & $\begin{array}{c}\text { (1) } \\
\text { All Surges } \\
\text { (Advanced) }\end{array}$ & $\begin{array}{c}(2) \\
\text { Surges Leading } \\
\text { to Normal } \\
\text { (Advanced) }\end{array}$ & $\begin{array}{c}\text { (3) } \\
\text { Surges Leading } \\
\text { to Stop } \\
\text { (Advanced) }\end{array}$ & $\begin{array}{c}\text { (4) } \\
\text { All Surges } \\
\text { (Emerging) }\end{array}$ & $\begin{array}{c}(5) \\
\text { Surges Leading } \\
\text { to Normal } \\
\text { (Emerging) }\end{array}$ & $\begin{array}{c}(6) \\
\text { Surges Leading } \\
\text { to Stop } \\
\text { (Emerging) }\end{array}$ \\
\hline Global Growth $_{\mathrm{t}}$ & $\begin{array}{l}-0.531 \\
(0.484)\end{array}$ & $\begin{array}{l}-0.523 \\
(0.728)\end{array}$ & $\begin{array}{l}-0.430 \\
(0.750)\end{array}$ & $\begin{array}{c}0.330 * * * \\
(0.123)\end{array}$ & $\begin{array}{c}0.280 * * \\
(0.138)\end{array}$ & $\begin{array}{c}0.047 \\
(0.349)\end{array}$ \\
\hline Global Interest Rate $_{\mathrm{t}}$ & $\begin{array}{c}-0.092 * * * \\
(0.027)\end{array}$ & $\begin{array}{c}-0.099 * * * \\
(0.029)\end{array}$ & $\begin{array}{l}-0.101 \\
(0.064)\end{array}$ & $\begin{array}{l}-0.005 \\
(0.009)\end{array}$ & $\begin{array}{l}-0.003 \\
(0.010)\end{array}$ & $\begin{array}{l}-0.032 \\
(0.027)\end{array}$ \\
\hline Global Liquidity Growth $_{\mathrm{t}}$ & $\begin{array}{l}-0.033 \\
(0.045)\end{array}$ & $\begin{array}{l}-0.100 \\
(0.062)\end{array}$ & $\begin{array}{l}-0.078 \\
(0.092)\end{array}$ & $\begin{array}{c}0.026 \\
(0.021)\end{array}$ & $\begin{array}{l}0.041^{*} \\
(0.022)\end{array}$ & $\begin{array}{l}-0.051 \\
(0.050)\end{array}$ \\
\hline Global Commodity Price $_{\mathrm{t}}$ & $\begin{array}{l}-0.079 \\
(0.192)\end{array}$ & $\begin{array}{l}-0.247 \\
(0.236)\end{array}$ & $\begin{array}{c}0.174 \\
(0.362)\end{array}$ & $\begin{array}{l}-0.054 \\
(0.040)\end{array}$ & $\begin{array}{l}-0.029 \\
(0.050)\end{array}$ & $\begin{array}{l}-0.055 \\
(0.087)\end{array}$ \\
\hline Global Risk Aversion $_{\mathrm{t}}$ & $\begin{array}{c}-0.154^{* *} \\
(0.066)\end{array}$ & $\begin{array}{l}-0.106 \\
(0.065)\end{array}$ & $\begin{array}{c}-0.387^{* *} \\
(0.193)\end{array}$ & $\begin{array}{l}-0.028 \\
(0.021)\end{array}$ & $\begin{array}{c}-0.053^{* * *} \\
(0.019)\end{array}$ & $\begin{array}{l}-0.003 \\
(0.051)\end{array}$ \\
\hline Domestic Output Gap ${ }_{i, t}$ & $\begin{array}{c}0.751^{*} \\
(0.429)\end{array}$ & $\begin{array}{c}0.185 \\
(0.418)\end{array}$ & $\begin{array}{l}1.694^{*} \\
(0.869)\end{array}$ & $\begin{array}{c}0.332^{* * *} \\
(0.059)\end{array}$ & $\begin{array}{l}-0.002 \\
(0.076)\end{array}$ & $\begin{array}{c}0.438 * * * \\
(0.086)\end{array}$ \\
\hline Market Capitalisation $_{i, t}$ & $\begin{array}{c}0.002 \\
(0.014)\end{array}$ & $\begin{array}{c}0.035^{* *} \\
(0.018)\end{array}$ & $\begin{array}{l}-0.047^{*} \\
(0.026)\end{array}$ & $\begin{array}{c}0.000 \\
(0.006)\end{array}$ & $\begin{array}{l}-0.007 \\
(0.007)\end{array}$ & $\begin{array}{c}0.010 \\
(0.009)\end{array}$ \\
\hline Domestic Credit $_{i, t}$ & $\begin{array}{c}0.063^{* * *} \\
(0.019)\end{array}$ & $\begin{array}{l}0.047^{* *} \\
(0.021)\end{array}$ & $\begin{array}{c}0.085 * * \\
(0.043)\end{array}$ & $\begin{array}{c}0.010^{*} \\
(0.006)\end{array}$ & $\begin{array}{c}0.011 \\
(0.010)\end{array}$ & $\begin{array}{c}0.001 \\
(0.007)\end{array}$ \\
\hline Capital Openness ${ }_{i, t}$ & $\begin{array}{c}-0.012 \\
(0.025)\end{array}$ & $\begin{array}{l}-0.032 \\
(0.032)\end{array}$ & $\begin{array}{c}0.014 \\
(0.038)\end{array}$ & $\begin{array}{c}0.035^{* * *} \\
(0.005)\end{array}$ & $\begin{array}{c}0.038^{* * *} \\
(0.007)\end{array}$ & $\begin{array}{c}0.023^{* * *} \\
(0.009)\end{array}$ \\
\hline Per Capita Income ${ }_{i, t}$ & $\begin{array}{c}0.349 * * * \\
(0.096)\end{array}$ & $\begin{array}{c}0.356 * * * \\
(0.101)\end{array}$ & $\begin{array}{l}-0.098 \\
(0.231)\end{array}$ & $\begin{array}{l}0.028^{*} \\
(0.015)\end{array}$ & $\begin{array}{c}0.012 \\
(0.015)\end{array}$ & $\begin{array}{l}0.098^{* *} \\
(0.038)\end{array}$ \\
\hline Real Appreciation $n_{i, t}$ & $\begin{array}{c}0.042 \\
(0.071)\end{array}$ & $\begin{array}{c}0.025 \\
(0.102)\end{array}$ & $\begin{array}{c}0.025 \\
(0.109)\end{array}$ & $\begin{array}{c}0.009 \\
(0.012)\end{array}$ & $\begin{array}{l}0.019 * * \\
(0.009)\end{array}$ & $\begin{array}{c}0.049 \\
(0.044)\end{array}$ \\
\hline Constant & $\begin{array}{c}-21.808^{*} \\
(11.437)\end{array}$ & $\begin{array}{l}-14.219 \\
(13.944)\end{array}$ & $\begin{array}{c}10.377 \\
(25.813)\end{array}$ & $\begin{array}{l}-0.198 \\
(2.195)\end{array}$ & $\begin{array}{c}0.160 \\
(2.506)\end{array}$ & $\begin{array}{l}-3.625 \\
(4.789)\end{array}$ \\
\hline $\begin{array}{l}\text { Observations } \\
\text { R-squared }\end{array}$ & $\begin{array}{c}381 \\
0.219\end{array}$ & $\begin{array}{c}262 \\
0.229\end{array}$ & $\begin{array}{c}119 \\
0.334\end{array}$ & $\begin{array}{c}481 \\
0.354\end{array}$ & $\begin{array}{c}285 \\
0.312\end{array}$ & $\begin{array}{c}196 \\
0.401\end{array}$ \\
\hline
\end{tabular}

Notes: Dependent variable is gross capital inflows in percent of nominal GDP conditional on being in surge types. Global growth, global liquidity growth, and real appreciation are year-on-year quarterly changes in percent. Global interest rate is in percent per annum. Commodity price index and per capita income are in natural log values multiplied by 10 and 100 , respectively. Domestic output gap pertains to the difference of actual and potential output in percent. Market capitalization and domestic credit are in percent of nominal GDP. Capital account openness refers to the standardized Chinn-Ito (2006) index and scaled to 100. Robust standard errors are in parentheses. ${ }^{* * *} \mathrm{p}<0.01,{ }^{* *} \mathrm{p}<0.05,{ }^{*} \mathrm{p}<0.1$. 
Table 8: Sensitivity Test Using Lagged Value of the Regressors

\begin{tabular}{|c|c|c|c|c|c|c|c|c|}
\hline VARIABLES & $\begin{array}{c}\text { (1) } \\
\text { All } \\
\text { Economies }\end{array}$ & $\begin{array}{c}\text { (2) } \\
\text { Advanced } \\
\text { Economies }\end{array}$ & $\begin{array}{c}\text { (3) } \\
\text { Emerging } \\
\text { Economies }\end{array}$ & All Surges & $\begin{array}{c}5) \\
\text { Surges } \\
\text { Leading to } \\
\text { Normal } \\
\end{array}$ & $\begin{array}{c}\text { (6) } \\
\text { Surges } \\
\text { Leading to } \\
\text { Stop }\end{array}$ & $\begin{array}{c}\text { (7) } \\
\text { All Surges } \\
\text { Advanced }\end{array}$ & $\begin{array}{c}\text { (8) } \\
\text { All Surges } \\
\text { Emerging }\end{array}$ \\
\hline Global Growth $_{\mathrm{t}-1}$ & $\begin{array}{c}0.027 \\
(0.022)\end{array}$ & $\begin{array}{l}-0.034 \\
(0.030)\end{array}$ & $\begin{array}{c}0.099^{* * *} \\
(0.034)\end{array}$ & $\begin{array}{c}0.438^{* *} \\
(0.180)\end{array}$ & $\begin{array}{c}0.505^{* *} \\
(0.219)\end{array}$ & $\begin{array}{c}0.083 \\
(0.354)\end{array}$ & $\begin{array}{l}-0.100 \\
(0.430)\end{array}$ & $\begin{array}{c}0.339 * * * \\
(0.109)\end{array}$ \\
\hline Global Interest Rate $_{t-1}$ & $\begin{array}{l}-0.002 \\
(0.002)\end{array}$ & $\begin{array}{l}-0.001 \\
(0.002)\end{array}$ & $\begin{array}{l}-0.003 \\
(0.003)\end{array}$ & $\begin{array}{c}-0.047^{* * *} \\
(0.013)\end{array}$ & $\begin{array}{c}-0.052^{* * *} \\
(0.015)\end{array}$ & $\begin{array}{c}-0.040^{* *} \\
(0.019)\end{array}$ & $\begin{array}{c}-0.081^{* * *} \\
(0.025)\end{array}$ & $\begin{array}{l}-0.005 \\
(0.007)\end{array}$ \\
\hline Global Liquidity Growth $_{\mathrm{t}-1}$ & $\begin{array}{l}0.004^{*} \\
(0.002)\end{array}$ & $\begin{array}{c}0.002 \\
(0.003)\end{array}$ & $\begin{array}{c}0.006 \\
(0.004)\end{array}$ & $\begin{array}{l}-0.028 \\
(0.028)\end{array}$ & $\begin{array}{l}-0.064^{*} \\
(0.038)\end{array}$ & $\begin{array}{l}-0.045 \\
(0.038)\end{array}$ & $\begin{array}{l}-0.037 \\
(0.049)\end{array}$ & $\begin{array}{c}0.017 \\
(0.019)\end{array}$ \\
\hline Global Commodity Price $_{\mathrm{t}-1}$ & $\begin{array}{c}0.000 \\
(0.006)\end{array}$ & $\begin{array}{c}0.015 \\
(0.011)\end{array}$ & $\begin{array}{l}-0.001 \\
(0.009)\end{array}$ & $\begin{array}{c}0.046 \\
(0.067)\end{array}$ & $\begin{array}{l}-0.109 \\
(0.086)\end{array}$ & $\begin{array}{l}0.307^{* *} \\
(0.131)\end{array}$ & $\begin{array}{c}0.104 \\
(0.202)\end{array}$ & $\begin{array}{l}-0.053 \\
(0.041)\end{array}$ \\
\hline Global Risk Aversion $_{\mathrm{t}-1}$ & $\begin{array}{c}-0.012^{* * *} \\
(0.003)\end{array}$ & $\begin{array}{l}-0.010^{* *} \\
(0.004)\end{array}$ & $\begin{array}{c}-0.012^{* *} \\
(0.005)\end{array}$ & $\begin{array}{l}-0.055 \\
(0.039)\end{array}$ & $\begin{array}{l}-0.034 \\
(0.044)\end{array}$ & $\begin{array}{l}-0.110 \\
(0.074)\end{array}$ & $\begin{array}{l}-0.069 \\
(0.093)\end{array}$ & $\begin{array}{l}-0.028 \\
(0.020)\end{array}$ \\
\hline Domestic Output Gap $_{\mathrm{i}, \mathrm{t}-1}$ & $\begin{array}{c}0.081^{* * *} \\
(0.011)\end{array}$ & $\begin{array}{c}0.069 * * * \\
(0.020)\end{array}$ & $\begin{array}{c}0.089 * * * \\
(0.014)\end{array}$ & $\begin{array}{l}0.300^{* *} \\
(0.117)\end{array}$ & $\begin{array}{l}-0.019 \\
(0.166)\end{array}$ & $\begin{array}{c}0.443^{* * *} \\
(0.163)\end{array}$ & $\begin{array}{c}0.519 \\
(0.465)\end{array}$ & $\begin{array}{c}0.303^{* * *} \\
(0.061)\end{array}$ \\
\hline Market Capitalisation $_{\mathrm{i}, \mathrm{t}-\mathrm{1}}$ & $\begin{array}{c}0.001 \\
(0.000)\end{array}$ & $\begin{array}{c}0.001 \\
(0.001)\end{array}$ & $\begin{array}{l}-0.001 \\
(0.001)\end{array}$ & $\begin{array}{l}-0.009 \\
(0.007)\end{array}$ & $\begin{array}{l}-0.002 \\
(0.008)\end{array}$ & $\begin{array}{l}-0.017 \\
(0.013)\end{array}$ & $\begin{array}{c}0.002 \\
(0.015)\end{array}$ & $\begin{array}{c}0.002 \\
(0.006)\end{array}$ \\
\hline Domestic Credit $_{\mathrm{i},-1}$ & $\begin{array}{c}0.001 \\
(0.001)\end{array}$ & $\begin{array}{l}-0.001^{*} \\
(0.001)\end{array}$ & $\begin{array}{c}0.003^{* * *} \\
(0.001)\end{array}$ & $\begin{array}{c}0.041^{* * *} \\
(0.012)\end{array}$ & $\begin{array}{l}0.033^{* *} \\
(0.015)\end{array}$ & $\begin{array}{c}0.056^{* *} \\
(0.023)\end{array}$ & $\begin{array}{c}0.057^{* * *} \\
(0.019)\end{array}$ & $\begin{array}{c}0.009 \\
(0.006)\end{array}$ \\
\hline Capital Openness $s_{i, t-1}$ & $\begin{array}{l}-0.000 \\
(0.001)\end{array}$ & $\begin{array}{l}0.002^{*} \\
(0.001)\end{array}$ & $\begin{array}{c}-0.001 \\
(0.001)\end{array}$ & $\begin{array}{l}0.017^{*} \\
(0.010)\end{array}$ & $\begin{array}{c}0.011 \\
(0.015)\end{array}$ & $\begin{array}{c}0.027^{* * *} \\
(0.008)\end{array}$ & $\begin{array}{l}-0.016 \\
(0.024)\end{array}$ & $\begin{array}{c}0.036 * * * \\
(0.005)\end{array}$ \\
\hline Per Capita Income $e_{i, t-1}$ & $\begin{array}{l}-0.002 \\
(0.002)\end{array}$ & $\begin{array}{l}-0.003 \\
(0.004)\end{array}$ & $\begin{array}{l}-0.003 \\
(0.003)\end{array}$ & $\begin{array}{c}0.097^{* * *} \\
(0.033)\end{array}$ & $\begin{array}{c}0.115^{* * *} \\
(0.039)\end{array}$ & $\begin{array}{c}0.056 \\
(0.040)\end{array}$ & $\begin{array}{c}0.363^{* * *} \\
(0.102)\end{array}$ & $\begin{array}{l}0.038^{* *} \\
(0.015)\end{array}$ \\
\hline Real Appreciation $n_{i, t-1}$ & $\begin{array}{c}0.000 \\
(0.002)\end{array}$ & $\begin{array}{c}0.003 \\
(0.004)\end{array}$ & $\begin{array}{l}-0.001 \\
(0.003)\end{array}$ & $\begin{array}{c}0.011 \\
(0.022)\end{array}$ & $\begin{array}{c}0.020 \\
(0.025)\end{array}$ & $\begin{array}{c}0.049 \\
(0.048)\end{array}$ & $\begin{array}{c}0.042 \\
(0.070)\end{array}$ & $\begin{array}{l}-0.001 \\
(0.010)\end{array}$ \\
\hline Constant & & & & $\begin{array}{c}-9.570^{* * *} \\
(3.597)\end{array}$ & $\begin{array}{l}-3.936 \\
(4.357)\end{array}$ & $\begin{array}{c}-17.058^{* *} \\
(7.003)\end{array}$ & $\begin{array}{c}-33.131^{* * *} \\
(11.680)\end{array}$ & $\begin{array}{l}-0.874 \\
(2.125)\end{array}$ \\
\hline Estimation & Probit & Probit & Probit & Pooled OLS & Pooled OLS & Pooled OLS & Pooled OLS & Pooled OLS \\
\hline Observations & 858 & 379 & 479 & 858 & 546 & 312 & 379 & 479 \\
\hline R-squared & 0.134 & 0.070 & 0.212 & 0.193 & 0.174 & 0.262 & 0.198 & 0.353 \\
\hline
\end{tabular}

Notes: Columns (1) to (3) show the marginal effects (at means) of probit estimates for the occurrence of surges ending in stops for the all, advanced and emerging economies. Dependent variables for Columns (1) to (3) are dummy variable which takes the value of 1 if surges lead to stops and 0 for surges ending in normal episode. R-squared refers to Pseudo R-squared. Columns (4) to (6) test the significance of global and domestic factors on the magnitude of gross inflows for surges and its two types. Columns (7) and (8) present the results for all surges split by economy types. Dependent variables for Columns (4) to (8) are gross capital inflows in percent of nominal GDP conditional on being in surge types. Standard errors are in parentheses. ${ }^{* *} p<0.01,{ }^{* *} p<0.05,{ }^{*} p<0.1$. 
Table 9: Sensitivity Test Excluding Real Exchange Rate Appreciation

\begin{tabular}{|c|c|c|c|c|c|c|c|c|}
\hline VARIABLES & $\begin{array}{c}\text { (1) } \\
\text { All } \\
\text { Economies }\end{array}$ & $\begin{array}{c}\text { (2) } \\
\text { Advanced } \\
\text { Economies }\end{array}$ & $\begin{array}{c}\text { (3) } \\
\text { Emerging } \\
\text { Economies }\end{array}$ & All Surges & $\begin{array}{c}\text { (5) } \\
\text { Surges } \\
\text { Leading to } \\
\text { Normal }\end{array}$ & $\begin{array}{c}(6) \\
\text { Surges } \\
\text { Leading to } \\
\text { Stop }\end{array}$ & $\begin{array}{c}\text { (7) } \\
\text { All Surges } \\
\text { Advanced }\end{array}$ & $\begin{array}{c}\text { (8) } \\
\text { All Surges } \\
\text { Emerging }\end{array}$ \\
\hline Global Growth $_{\mathrm{t}}$ & $\begin{array}{c}0.013 \\
(0.021)\end{array}$ & $\begin{array}{l}-0.054^{*} \\
(0.032)\end{array}$ & $\begin{array}{l}0.066^{* *} \\
(0.030)\end{array}$ & $\begin{array}{c}0.182 \\
(0.198)\end{array}$ & $\begin{array}{c}0.336 \\
(0.254)\end{array}$ & $\begin{array}{l}-0.489 \\
(0.376)\end{array}$ & $\begin{array}{l}-0.527 \\
(0.484)\end{array}$ & $\begin{array}{c}0.205 \\
(0.128)\end{array}$ \\
\hline Global Interest Rate $_{t}$ & $\begin{array}{l}-0.001 \\
(0.002)\end{array}$ & $\begin{array}{l}-0.001 \\
(0.002)\end{array}$ & $\begin{array}{l}-0.003 \\
(0.003)\end{array}$ & $\begin{array}{c}-0.053^{* * *} \\
(0.014)\end{array}$ & $\begin{array}{c}-0.060^{* * *} \\
(0.016)\end{array}$ & $\begin{array}{l}-0.047^{* *} \\
(0.022)\end{array}$ & $\begin{array}{c}-0.091^{* * *} \\
(0.027)\end{array}$ & $\begin{array}{l}-0.003 \\
(0.008)\end{array}$ \\
\hline Global Liquidity Growth $_{t}$ & $\begin{array}{c}0.001 \\
(0.002)\end{array}$ & $\begin{array}{l}-0.002 \\
(0.003)\end{array}$ & $\begin{array}{c}0.005 \\
(0.004)\end{array}$ & $\begin{array}{l}-0.027 \\
(0.027)\end{array}$ & $\begin{array}{l}-0.067^{*} \\
(0.037)\end{array}$ & $\begin{array}{l}-0.046 \\
(0.039)\end{array}$ & $\begin{array}{l}-0.027 \\
(0.046)\end{array}$ & $\begin{array}{c}0.015 \\
(0.020)\end{array}$ \\
\hline Global Commodity Price $_{\mathrm{t}}$ & $\begin{array}{c}0.001 \\
(0.006)\end{array}$ & $\begin{array}{c}0.013 \\
(0.012)\end{array}$ & $\begin{array}{c}0.002 \\
(0.008)\end{array}$ & $\begin{array}{c}0.009 \\
(0.066)\end{array}$ & $\begin{array}{l}-0.150^{*} \\
(0.086)\end{array}$ & $\begin{array}{c}0.346 * * * \\
(0.129)\end{array}$ & $\begin{array}{l}-0.079 \\
(0.193)\end{array}$ & $\begin{array}{l}-0.032 \\
(0.040)\end{array}$ \\
\hline Global Risk Aversion $_{\mathrm{t}}$ & $\begin{array}{c}-0.008^{* * *} \\
(0.003)\end{array}$ & $\begin{array}{l}-0.006 \\
(0.004)\end{array}$ & $\begin{array}{l}-0.010^{* *} \\
(0.005)\end{array}$ & $\begin{array}{c}-0.085^{* * *} \\
(0.030)\end{array}$ & $\begin{array}{c}-0.067^{* *} \\
(0.033)\end{array}$ & $\begin{array}{l}-0.119^{*} \\
(0.063)\end{array}$ & $\begin{array}{l}-0.153^{* *} \\
(0.065)\end{array}$ & $\begin{array}{l}-0.035^{*} \\
(0.019)\end{array}$ \\
\hline Domestic Output $\mathrm{Gap}_{\mathrm{i}, \mathrm{t}}$ & $\begin{array}{c}0.078^{* * *} \\
(0.010)\end{array}$ & $\begin{array}{c}0.059 * * * \\
(0.020)\end{array}$ & $\begin{array}{c}0.089^{* * *} \\
(0.015)\end{array}$ & $\begin{array}{c}0.325^{* * *} \\
(0.106)\end{array}$ & $\begin{array}{c}0.077 \\
(0.150)\end{array}$ & $\begin{array}{l}0.364^{* *} \\
(0.143)\end{array}$ & $\begin{array}{l}0.759^{*} \\
(0.429)\end{array}$ & $\begin{array}{c}0.265^{* * *} \\
(0.064)\end{array}$ \\
\hline Market Capitalisation $_{i, t}$ & $\begin{array}{c}0.000 \\
(0.000)\end{array}$ & $\begin{array}{c}0.001 \\
(0.001)\end{array}$ & $\begin{array}{l}-0.000 \\
(0.001)\end{array}$ & $\begin{array}{l}-0.009 \\
(0.006)\end{array}$ & $\begin{array}{l}-0.005 \\
(0.006)\end{array}$ & $\begin{array}{l}-0.014 \\
(0.012)\end{array}$ & $\begin{array}{c}0.003 \\
(0.014)\end{array}$ & $\begin{array}{c}0.002 \\
(0.005)\end{array}$ \\
\hline Domestic Credit $_{i, t}$ & $\begin{array}{c}0.000 \\
(0.001)\end{array}$ & $\begin{array}{l}-0.001 \\
(0.001)\end{array}$ & $\begin{array}{c}0.003^{* * *} \\
(0.001)\end{array}$ & $\begin{array}{c}0.044^{* * *} \\
(0.012)\end{array}$ & $\begin{array}{c}0.039 * * * \\
(0.015)\end{array}$ & $\begin{array}{l}0.055^{* *} \\
(0.021)\end{array}$ & $\begin{array}{c}0.063 * * * \\
(0.019)\end{array}$ & $\begin{array}{l}0.009^{*} \\
(0.005)\end{array}$ \\
\hline Capital Openness $s_{i, t}$ & $\begin{array}{l}-0.001 \\
(0.001)\end{array}$ & $\begin{array}{c}0.002 \\
(0.001)\end{array}$ & $\begin{array}{c}-0.002^{* *} \\
(0.001)\end{array}$ & $\begin{array}{l}0.016^{*} \\
(0.009)\end{array}$ & $\begin{array}{c}0.010 \\
(0.014)\end{array}$ & $\begin{array}{c}0.025^{* * *} \\
(0.009)\end{array}$ & $\begin{array}{l}-0.014 \\
(0.025)\end{array}$ & $\begin{array}{c}0.032^{* * *} \\
(0.005)\end{array}$ \\
\hline Per Capita Income $e_{i, t}$ & $\begin{array}{l}-0.000 \\
(0.002)\end{array}$ & $\begin{array}{l}-0.002 \\
(0.005)\end{array}$ & $\begin{array}{l}-0.001 \\
(0.003)\end{array}$ & $\begin{array}{c}0.082^{* * *} \\
(0.028)\end{array}$ & $\begin{array}{c}0.099 * * * \\
(0.032)\end{array}$ & $\begin{array}{c}0.038 \\
(0.039)\end{array}$ & $\begin{array}{c}0.350^{* * *} \\
(0.096)\end{array}$ & $\begin{array}{l}0.035^{* *} \\
(0.015)\end{array}$ \\
\hline Constant & & & & $\begin{array}{l}-5.325 \\
(3.782)\end{array}$ & $\begin{array}{c}0.299 \\
(4.616)\end{array}$ & $\begin{array}{c}-14.941^{* *} \\
(6.271)\end{array}$ & $\begin{array}{l}-21.882^{*} \\
(11.408)\end{array}$ & $\begin{array}{l}-0.907 \\
(2.161)\end{array}$ \\
\hline Estimation & Probit & Probit & Probit & Pooled OLS & Pooled OLS & Pooled OLS & $\begin{array}{l}\text { Pooled OLS } \\
381\end{array}$ & $\begin{array}{c}\text { Pooled OLS } \\
518\end{array}$ \\
\hline $\begin{array}{l}\text { Observations } \\
\text { R-squared }\end{array}$ & $\begin{array}{c}899 \\
0.116\end{array}$ & $\begin{array}{c}381 \\
0.053\end{array}$ & $\begin{array}{c}518 \\
0.199\end{array}$ & $\begin{array}{c}899 \\
0.199\end{array}$ & $\begin{array}{c}580 \\
0.189\end{array}$ & $\begin{array}{c}319 \\
0.242\end{array}$ & $\begin{array}{c}381 \\
0.218\end{array}$ & $\begin{array}{c}518 \\
0.304\end{array}$ \\
\hline
\end{tabular}

Notes: Columns (1) to (3) show the marginal effects (at means) of probit estimates for the occurrence of surges ending in stops for the all, advanced and emerging economies. Dependent variables for Columns (1) to (3) are dummy variable which takes the value of 1 if surges lead to stops and 0 for surges ending in normal episode. R-squared refers to Pseudo R-squared. Columns (4) to (6) test the significance of global and domestic factors on the magnitude of gross inflows for surges and its two types. Columns (7) and (8) present the results for all surges split by economy types. Dependent variables for Columns (4) to (8) are gross capital inflows in percent of nominal GDP conditional on being in surge types. Standard errors are in parentheses. ${ }^{* * *} p<0.01,{ }^{* *} p<0.05,{ }^{*} p<0.1$. 
Table 10: Sensitivity Test Including Regional Contagion Dummy

\begin{tabular}{|c|c|c|c|c|c|c|c|c|}
\hline VARIABLES & $\begin{array}{c}\text { (1) } \\
\text { All } \\
\text { Economies }\end{array}$ & $\begin{array}{c}\text { (2) } \\
\text { Advanced } \\
\text { Economies }\end{array}$ & $\begin{array}{c}\text { (3) } \\
\text { Emerging } \\
\text { Economies }\end{array}$ & All Surges & $\begin{array}{c}\text { (5) } \\
\text { Surges } \\
\text { Leading to } \\
\text { Normal } \\
\end{array}$ & $\begin{array}{c}(6) \\
\text { Surges } \\
\text { Leading to } \\
\text { Stop }\end{array}$ & $\begin{array}{c}\text { (7) } \\
\text { All Surges } \\
\text { Advanced }\end{array}$ & $\begin{array}{c}\text { (8) } \\
\text { All Surges } \\
\text { Emerging }\end{array}$ \\
\hline Global Growth $_{\mathrm{t}}$ & $\begin{array}{c}0.026 \\
(0.022)\end{array}$ & $\begin{array}{l}-0.060^{*} \\
(0.032)\end{array}$ & $\begin{array}{c}0.113^{* * *} \\
(0.035)\end{array}$ & $\begin{array}{c}0.226 \\
(0.206)\end{array}$ & $\begin{array}{c}0.303 \\
(0.281)\end{array}$ & $\begin{array}{l}-0.083 \\
(0.333)\end{array}$ & $\begin{array}{l}-0.406 \\
(0.487)\end{array}$ & $\begin{array}{c}0.335^{* * *} \\
(0.127)\end{array}$ \\
\hline Global Interest Rate $_{t}$ & $\begin{array}{l}-0.000 \\
(0.002)\end{array}$ & $\begin{array}{l}-0.001 \\
(0.002)\end{array}$ & $\begin{array}{l}-0.001 \\
(0.003)\end{array}$ & $\begin{array}{c}-0.060^{* * *} \\
(0.015)\end{array}$ & $\begin{array}{c}-0.068^{* * *} \\
(0.018)\end{array}$ & $\begin{array}{c}-0.047^{* *} \\
(0.023)\end{array}$ & $\begin{array}{c}-0.098^{* * *} \\
(0.028)\end{array}$ & $\begin{array}{l}-0.004 \\
(0.009)\end{array}$ \\
\hline Global Liquidity Growth $_{\mathrm{t}}$ & $\begin{array}{c}0.001 \\
(0.002)\end{array}$ & $\begin{array}{l}-0.003 \\
(0.003)\end{array}$ & $\begin{array}{c}0.007 \\
(0.004)\end{array}$ & $\begin{array}{l}-0.021 \\
(0.028)\end{array}$ & $\begin{array}{l}-0.065^{*} \\
(0.039)\end{array}$ & $\begin{array}{l}-0.037 \\
(0.040)\end{array}$ & $\begin{array}{l}-0.035 \\
(0.044)\end{array}$ & $\begin{array}{c}0.025 \\
(0.021)\end{array}$ \\
\hline Global Commodity Price $_{t}$ & $\begin{array}{c}0.000 \\
(0.006)\end{array}$ & $\begin{array}{c}0.013 \\
(0.012)\end{array}$ & $\begin{array}{c}0.002 \\
(0.009)\end{array}$ & $\begin{array}{c}0.002 \\
(0.070)\end{array}$ & $\begin{array}{l}-0.174^{*} \\
(0.091)\end{array}$ & $\begin{array}{l}0.293^{* *} \\
(0.127)\end{array}$ & $\begin{array}{l}-0.035 \\
(0.194)\end{array}$ & $\begin{array}{l}-0.056 \\
(0.040)\end{array}$ \\
\hline Global Risk Aversion $_{\mathrm{t}}$ & $\begin{array}{c}-0.008^{* *} \\
(0.003)\end{array}$ & $\begin{array}{l}-0.006 \\
(0.004)\end{array}$ & $\begin{array}{l}-0.010^{*} \\
(0.006)\end{array}$ & $\begin{array}{c}-0.100^{* * *} \\
(0.034)\end{array}$ & $\begin{array}{c}-0.077^{* *} \\
(0.036)\end{array}$ & $\begin{array}{c}-0.157^{* *} \\
(0.076)\end{array}$ & $\begin{array}{l}-0.173^{* *} \\
(0.067)\end{array}$ & $\begin{array}{l}-0.026 \\
(0.021)\end{array}$ \\
\hline Domestic Output $\mathrm{Gap}_{\mathrm{i}, \mathrm{t}}$ & $\begin{array}{c}0.085 * * * \\
(0.011)\end{array}$ & $\begin{array}{c}0.059 * * * \\
(0.020)\end{array}$ & $\begin{array}{l}0.112^{* * *} \\
(0.015)\end{array}$ & $\begin{array}{c}0.428^{* * *} \\
(0.122)\end{array}$ & $\begin{array}{c}0.072 \\
(0.173)\end{array}$ & $\begin{array}{c}0.632^{* * *} \\
(0.163)\end{array}$ & $\begin{array}{c}0.675 \\
(0.422)\end{array}$ & $\begin{array}{c}0.326 * * * \\
(0.068)\end{array}$ \\
\hline Market Capitalisation $_{i, t}$ & $\begin{array}{c}0.001 \\
(0.000)\end{array}$ & $\begin{array}{c}0.000 \\
(0.001)\end{array}$ & $\begin{array}{l}-0.001 \\
(0.001)\end{array}$ & $\begin{array}{l}-0.010 \\
(0.007)\end{array}$ & $\begin{array}{l}-0.007 \\
(0.008)\end{array}$ & $\begin{array}{l}-0.016 \\
(0.011)\end{array}$ & $\begin{array}{c}0.009 \\
(0.013)\end{array}$ & $\begin{array}{c}0.001 \\
(0.006)\end{array}$ \\
\hline Domestic Credit $_{i, \mathrm{t}}$ & $\begin{array}{c}0.000 \\
(0.001)\end{array}$ & $\begin{array}{l}-0.001 \\
(0.001)\end{array}$ & $\begin{array}{l}0.004^{* * *} \\
(0.001)\end{array}$ & $\begin{array}{c}0.044^{* * *} \\
(0.012)\end{array}$ & $\begin{array}{l}0.040^{* *} \\
(0.016)\end{array}$ & $\begin{array}{c}0.055^{* * *} \\
(0.021)\end{array}$ & $\begin{array}{c}0.064^{* * *} \\
(0.019)\end{array}$ & $\begin{array}{l}0.010^{*} \\
(0.006)\end{array}$ \\
\hline Capital Openness $s_{i, t}$ & $\begin{array}{l}-0.000 \\
(0.001)\end{array}$ & $\begin{array}{c}0.002 \\
(0.001)\end{array}$ & $\begin{array}{l}-0.001 \\
(0.001)\end{array}$ & $\begin{array}{l}0.018^{*} \\
(0.010)\end{array}$ & $\begin{array}{c}0.008 \\
(0.015)\end{array}$ & $\begin{array}{c}0.033 * * * \\
(0.009)\end{array}$ & $\begin{array}{l}-0.015 \\
(0.024)\end{array}$ & $\begin{array}{c}0.035 * * * \\
(0.005)\end{array}$ \\
\hline Per Capita Income ${ }_{i, t}$ & $\begin{array}{l}-0.003 \\
(0.002)\end{array}$ & $\begin{array}{l}-0.003 \\
(0.005)\end{array}$ & $\begin{array}{l}-0.006^{*} \\
(0.003)\end{array}$ & $\begin{array}{c}0.086^{* * *} \\
(0.031)\end{array}$ & $\begin{array}{c}0.110^{* * *} \\
(0.037)\end{array}$ & $\begin{array}{c}0.035 \\
(0.040)\end{array}$ & $\begin{array}{c}0.358^{* * *} \\
(0.096)\end{array}$ & $\begin{array}{l}0.028^{*} \\
(0.015)\end{array}$ \\
\hline Real Appreciation $n_{i, t}$ & $\begin{array}{c}0.002 \\
(0.002)\end{array}$ & $\begin{array}{l}0.008^{*} \\
(0.004)\end{array}$ & $\begin{array}{c}0.002 \\
(0.003)\end{array}$ & $\begin{array}{c}0.022 \\
(0.025)\end{array}$ & $\begin{array}{c}0.031 \\
(0.029)\end{array}$ & $\begin{array}{c}0.042 \\
(0.050)\end{array}$ & $\begin{array}{c}0.025 \\
(0.070)\end{array}$ & $\begin{array}{c}0.009 \\
(0.012)\end{array}$ \\
\hline Regional Contagion $n_{i, t}$ & $\begin{array}{l}-0.003 \\
(0.053)\end{array}$ & $\begin{array}{c}0.090 \\
(0.100)\end{array}$ & $\begin{array}{l}-0.046 \\
(0.068)\end{array}$ & $\begin{array}{c}-1.395^{* *} \\
(0.690)\end{array}$ & $\begin{array}{l}-0.288 \\
(0.990)\end{array}$ & $\begin{array}{c}-3.184^{* * *} \\
(1.057)\end{array}$ & $\begin{array}{c}-5.458^{* * *} \\
(1.757)\end{array}$ & $\begin{array}{c}0.129 \\
(0.461)\end{array}$ \\
\hline Constant & & & & $\begin{array}{r}-5.316 \\
(3.901)\end{array}$ & $\begin{array}{c}0.901 \\
(4.757)\end{array}$ & $\begin{array}{c}-13.585^{* *} \\
(6.463)\end{array}$ & $\begin{array}{c}-24.379^{* *} \\
(11.459)\end{array}$ & $\begin{array}{l}-0.181 \\
(2.199)\end{array}$ \\
\hline Estimation & Probit & Probit & Probit & Pooled OLS & Pooled OLS & Pooled OLS & Pooled OLS & Pooled OLS \\
\hline Observations & 862 & 381 & 481 & 862 & 547 & 315 & 381 & 481 \\
\hline R-squared & 0.129 & 0.061 & 0.237 & 0.209 & 0.189 & 0.288 & 0.236 & 0.355 \\
\hline
\end{tabular}

Notes: Regional contagion is a dummy variable which takes the value of 1 if more than half of the economies in the region are experiencing surges and 0 if no or less than half of the economies in the region are experiencing a surge. Columns (1) to (3) show the marginal effects (at means) of probit estimates for the occurrence of surges ending in stops for the all, advanced and emerging economies. Dependent variables for Columns (1) to (3) are dummy variable which takes the value of 1 if surges lead to stops and 0 for surges ending in normal episode. R-squared refers to Pseudo R-squared. Columns (4) to (6) test the significance of global and domestic factors on the magnitude of gross inflows for surges and its two types. Columns (7) and (8) present the results for all surges split by economy types. Dependent variables for Columns (4) to (8) are gross capital inflows in percent of nominal GDP conditional on being in surge types. Standard errors are in parentheses. ${ }^{* *} \mathrm{p}<0.01,{ }^{* *} \mathrm{p}<0.05,{ }^{*} \mathrm{p}<0.1$. 
Table 11: Sensitivity Test Using Eight Quarters of Normal Episode as Cut-Off

\begin{tabular}{|c|c|c|c|c|c|c|c|c|}
\hline VARIABLES & $\begin{array}{c}\text { (1) } \\
\text { All } \\
\text { Economies }\end{array}$ & $\begin{array}{c}\text { (2) } \\
\text { Advanced } \\
\text { Economies }\end{array}$ & $\begin{array}{c}\text { (3) } \\
\text { Emerging } \\
\text { Economies }\end{array}$ & $\begin{array}{c}\text { (4) } \\
\text { All Surges }\end{array}$ & $\begin{array}{c}\text { (5) } \\
\text { Surges } \\
\text { Leading to } \\
\text { Normal }\end{array}$ & $\begin{array}{c}(6) \\
\text { Surges } \\
\text { Leading to } \\
\text { Stop }\end{array}$ & $\begin{array}{c}\text { (7) } \\
\text { All Surges } \\
\text { Advanced }\end{array}$ & $\begin{array}{c}\text { (8) } \\
\text { All Surges } \\
\text { Emerging }\end{array}$ \\
\hline Global Growth $_{\mathrm{t}}$ & $\begin{array}{c}0.021 \\
(0.023)\end{array}$ & $\begin{array}{l}-0.019 \\
(0.035)\end{array}$ & $\begin{array}{c}0.047 \\
(0.033)\end{array}$ & $\begin{array}{c}0.243 \\
(0.206)\end{array}$ & $\begin{array}{c}0.369 \\
(0.317)\end{array}$ & $\begin{array}{l}-0.120 \\
(0.280)\end{array}$ & $\begin{array}{l}-0.531 \\
(0.484)\end{array}$ & $\begin{array}{c}0.330^{* * *} \\
(0.123)\end{array}$ \\
\hline Global Interest Rate $_{\mathrm{t}}$ & $\begin{array}{l}-0.000 \\
(0.002)\end{array}$ & $\begin{array}{c}0.001 \\
(0.002)\end{array}$ & $\begin{array}{l}-0.001 \\
(0.003)\end{array}$ & $\begin{array}{c}-0.057^{* * *} \\
(0.015)\end{array}$ & $\begin{array}{c}-0.077^{* * *} \\
(0.021)\end{array}$ & $\begin{array}{l}-0.025 \\
(0.017)\end{array}$ & $\begin{array}{c}-0.092^{* * *} \\
(0.027)\end{array}$ & $\begin{array}{l}-0.005 \\
(0.009)\end{array}$ \\
\hline Global Liquidity Growth $_{\mathrm{t}}$ & $\begin{array}{l}-0.001 \\
(0.003)\end{array}$ & $\begin{array}{l}-0.006^{*} \\
(0.003)\end{array}$ & $\begin{array}{l}0.007^{*} \\
(0.004)\end{array}$ & $\begin{array}{l}-0.024 \\
(0.028)\end{array}$ & $\begin{array}{c}-0.095^{* *} \\
(0.041)\end{array}$ & $\begin{array}{l}-0.008 \\
(0.040)\end{array}$ & $\begin{array}{l}-0.033 \\
(0.045)\end{array}$ & $\begin{array}{c}0.026 \\
(0.021)\end{array}$ \\
\hline Global Commodity Price $_{t}$ & $\begin{array}{l}-0.001 \\
(0.007)\end{array}$ & $\begin{array}{c}0.019 \\
(0.013)\end{array}$ & $\begin{array}{l}-0.009 \\
(0.009)\end{array}$ & $\begin{array}{l}-0.017 \\
(0.068)\end{array}$ & $\begin{array}{c}-0.265^{* * *} \\
(0.096)\end{array}$ & $\begin{array}{c}0.249^{* *} \\
(0.118)\end{array}$ & $\begin{array}{l}-0.079 \\
(0.192)\end{array}$ & $\begin{array}{l}-0.054 \\
(0.040)\end{array}$ \\
\hline Global Risk Aversion $_{t}$ & $\begin{array}{l}-0.008^{* *} \\
(0.003)\end{array}$ & $\begin{array}{l}-0.001 \\
(0.004)\end{array}$ & $\begin{array}{c}-0.015^{* * *} \\
(0.005)\end{array}$ & $\begin{array}{c}-0.088^{* * *} \\
(0.032)\end{array}$ & $\begin{array}{l}-0.066^{*} \\
(0.038)\end{array}$ & $\begin{array}{l}-0.098^{*} \\
(0.057)\end{array}$ & $\begin{array}{c}-0.154^{* *} \\
(0.066)\end{array}$ & $\begin{array}{l}-0.028 \\
(0.021)\end{array}$ \\
\hline Domestic Output $\mathrm{Gap}_{\mathrm{i}, \mathrm{t}}$ & $\begin{array}{c}0.105^{* * *} \\
(0.013)\end{array}$ & $\begin{array}{c}0.080^{* * *} \\
(0.022)\end{array}$ & $\begin{array}{c}0.123^{* * *} \\
(0.016)\end{array}$ & $\begin{array}{c}0.380^{* * *} \\
(0.112)\end{array}$ & $\begin{array}{c}0.075 \\
(0.209)\end{array}$ & $\begin{array}{c}0.466^{* * *} \\
(0.134)\end{array}$ & $\begin{array}{l}0.751^{*} \\
(0.429)\end{array}$ & $\begin{array}{c}0.332^{* * *} \\
(0.059)\end{array}$ \\
\hline Market Capitalisation $_{i, t}$ & $\begin{array}{c}0.001 \\
(0.001)\end{array}$ & $\begin{array}{c}0.001 \\
(0.001)\end{array}$ & $\begin{array}{l}-0.001 \\
(0.001)\end{array}$ & $\begin{array}{l}-0.010 \\
(0.007)\end{array}$ & $\begin{array}{l}-0.008 \\
(0.009)\end{array}$ & $\begin{array}{l}-0.014 \\
(0.010)\end{array}$ & $\begin{array}{c}0.002 \\
(0.014)\end{array}$ & $\begin{array}{c}0.000 \\
(0.006)\end{array}$ \\
\hline Domestic Credit $_{i, t}$ & $\begin{array}{c}0.000 \\
(0.001)\end{array}$ & $\begin{array}{l}-0.001 \\
(0.001)\end{array}$ & $\begin{array}{c}0.004^{* * *} \\
(0.001)\end{array}$ & $\begin{array}{c}0.045^{* * *} \\
(0.013)\end{array}$ & $\begin{array}{c}0.047^{* * *} \\
(0.018)\end{array}$ & $\begin{array}{c}0.048^{* * *} \\
(0.018)\end{array}$ & $\begin{array}{c}0.063 * * * \\
(0.019)\end{array}$ & $\begin{array}{l}0.010^{*} \\
(0.006)\end{array}$ \\
\hline Capital Openness $\mathrm{i}_{\mathrm{i}, \mathrm{t}}$ & $\begin{array}{c}0.001 \\
(0.001)\end{array}$ & $\begin{array}{c}0.001 \\
(0.001)\end{array}$ & $\begin{array}{l}0.002^{* *} \\
(0.001)\end{array}$ & $\begin{array}{l}0.018^{*} \\
(0.010)\end{array}$ & $\begin{array}{c}0.001 \\
(0.017)\end{array}$ & $\begin{array}{c}0.031^{* * *} \\
(0.007)\end{array}$ & $\begin{array}{l}-0.012 \\
(0.025)\end{array}$ & $\begin{array}{c}0.035^{* * *} \\
(0.005)\end{array}$ \\
\hline Per Capita Income $e_{i, t}$ & $\begin{array}{l}-0.001 \\
(0.003)\end{array}$ & $\begin{array}{c}0.003 \\
(0.005)\end{array}$ & $\begin{array}{c}-0.008^{* *} \\
(0.004)\end{array}$ & $\begin{array}{c}0.087^{* * *} \\
(0.031)\end{array}$ & $\begin{array}{c}0.126^{* * *} \\
(0.043)\end{array}$ & $\begin{array}{c}0.044 \\
(0.029)\end{array}$ & $\begin{array}{c}0.349 * * * \\
(0.096)\end{array}$ & $\begin{array}{l}0.028^{*} \\
(0.015)\end{array}$ \\
\hline Real Appreciation ${ }_{i, t}$ & $\begin{array}{c}0.001 \\
(0.003)\end{array}$ & $\begin{array}{c}0.004 \\
(0.004)\end{array}$ & $\begin{array}{c}0.003 \\
(0.003)\end{array}$ & $\begin{array}{c}0.023 \\
(0.025)\end{array}$ & $\begin{array}{c}0.020 \\
(0.029)\end{array}$ & $\begin{array}{c}0.070 \\
(0.054)\end{array}$ & $\begin{array}{c}0.042 \\
(0.071)\end{array}$ & $\begin{array}{c}0.009 \\
(0.012)\end{array}$ \\
\hline Constant & & & & $\begin{array}{l}-4.867 \\
(3.909)\end{array}$ & $\begin{array}{c}3.651 \\
(5.086)\end{array}$ & $\begin{array}{c}-13.549 * * \\
(6.304)\end{array}$ & $\begin{array}{l}-21.808^{*} \\
(11.437)\end{array}$ & $\begin{array}{l}-0.198 \\
(2.195)\end{array}$ \\
\hline Estimation & Probit & Probit & Probit & Pooled OLS & Pooled OLS & Pooled OLS & Pooled OLS & Pooled OLS \\
\hline $\begin{array}{l}\text { Observations } \\
\text { R-squared }\end{array}$ & $\begin{array}{c}862 \\
0.139\end{array}$ & $\begin{array}{c}381 \\
0.076\end{array}$ & $\begin{array}{c}481 \\
0.227\end{array}$ & $\begin{array}{c}862 \\
0.205\end{array}$ & $\begin{array}{c}474 \\
0.209\end{array}$ & $\begin{array}{c}388 \\
0.239\end{array}$ & $\begin{array}{c}381 \\
0.219\end{array}$ & $\begin{array}{c}481 \\
0.354\end{array}$ \\
\hline
\end{tabular}


Table 12: Sensitivity Test Removing Global Interest Rate

\begin{tabular}{|c|c|c|c|c|c|c|c|c|}
\hline VARIABLES & $\begin{array}{c}\text { (1) } \\
\text { All } \\
\text { Economies }\end{array}$ & $\begin{array}{c}\text { (2) } \\
\text { Advanced } \\
\text { Economies }\end{array}$ & $\begin{array}{c}\text { (3) } \\
\text { Emerging } \\
\text { Economies }\end{array}$ & $\begin{array}{c}\text { (4) } \\
\text { All Surges }\end{array}$ & $\begin{array}{c}\text { (5) } \\
\text { Surges } \\
\text { Leading to } \\
\text { Normal } \\
\end{array}$ & $\begin{array}{c}\text { (6) } \\
\text { Surges } \\
\text { Leading to } \\
\text { Stop }\end{array}$ & $\begin{array}{c}\text { (7) } \\
\text { All Surges } \\
\text { Advanced }\end{array}$ & $\begin{array}{c}\text { (8) } \\
\text { All Surges } \\
\text { Emerging }\end{array}$ \\
\hline Global Growth $_{\mathrm{t}}$ & $\begin{array}{c}0.027 \\
(0.022)\end{array}$ & $\begin{array}{l}-0.054^{*} \\
(0.031)\end{array}$ & $\begin{array}{c}0.117^{* * *} \\
(0.033)\end{array}$ & $\begin{array}{l}0.451^{* *} \\
(0.199)\end{array}$ & $\begin{array}{l}0.496 * \\
(0.274)\end{array}$ & $\begin{array}{c}0.098 \\
(0.283)\end{array}$ & $\begin{array}{l}-0.127 \\
(0.443)\end{array}$ & $\begin{array}{c}0.342^{* * *} \\
(0.118)\end{array}$ \\
\hline Global Liquidity Growth $_{\mathrm{t}}$ & $\begin{array}{c}0.001 \\
(0.002)\end{array}$ & $\begin{array}{l}-0.003 \\
(0.003)\end{array}$ & $\begin{array}{c}0.006 \\
(0.004)\end{array}$ & $\begin{array}{l}-0.024 \\
(0.028)\end{array}$ & $\begin{array}{c}-0.062 \\
(0.039)\end{array}$ & $\begin{array}{r}-0.041 \\
(0.040)\end{array}$ & $\begin{array}{r}-0.019 \\
(0.045)\end{array}$ & $\begin{array}{c}0.025 \\
(0.021)\end{array}$ \\
\hline Global Commodity Price $_{t}$ & $\begin{array}{c}0.001 \\
(0.006)\end{array}$ & $\begin{array}{c}0.014 \\
(0.011)\end{array}$ & $\begin{array}{c}0.003 \\
(0.008)\end{array}$ & $\begin{array}{c}0.049 \\
(0.065)\end{array}$ & $\begin{array}{l}-0.090 \\
(0.085)\end{array}$ & $\begin{array}{l}0.293^{* *} \\
(0.126)\end{array}$ & $\begin{array}{c}0.035 \\
(0.187)\end{array}$ & $\begin{array}{l}-0.049 \\
(0.038)\end{array}$ \\
\hline Global Risk Aversion $_{\mathrm{t}}$ & $\begin{array}{c}-0.008^{* * *} \\
(0.003)\end{array}$ & $\begin{array}{l}-0.006 \\
(0.004)\end{array}$ & $\begin{array}{l}-0.009 \\
(0.005)\end{array}$ & $\begin{array}{c}-0.059^{* *} \\
(0.030)\end{array}$ & $\begin{array}{l}-0.043 \\
(0.033)\end{array}$ & $\begin{array}{l}-0.094 \\
(0.061)\end{array}$ & $\begin{array}{l}-0.098^{*} \\
(0.059)\end{array}$ & $\begin{array}{l}-0.026 \\
(0.020)\end{array}$ \\
\hline Domestic Output $\mathrm{Gap}_{\mathrm{i}, \mathrm{t}}$ & $\begin{array}{c}0.085 * * * \\
(0.011)\end{array}$ & $\begin{array}{c}0.057^{* * *} \\
(0.020)\end{array}$ & $\begin{array}{c}0.110^{* * *} \\
(0.015)\end{array}$ & $\begin{array}{c}0.375^{* * *} \\
(0.112)\end{array}$ & $\begin{array}{c}0.073 \\
(0.171)\end{array}$ & $\begin{array}{c}0.468^{* * *} \\
(0.140)\end{array}$ & $\begin{array}{l}0.710^{*} \\
(0.427)\end{array}$ & $\begin{array}{c}0.332^{* * *} \\
(0.059)\end{array}$ \\
\hline Market Capitalisation $_{\mathrm{i}, \mathrm{t}}$ & $\begin{array}{c}0.001 \\
(0.000)\end{array}$ & $\begin{array}{c}0.001 \\
(0.001)\end{array}$ & $\begin{array}{l}-0.001 \\
(0.001)\end{array}$ & $\begin{array}{l}-0.009 \\
(0.007)\end{array}$ & $\begin{array}{l}-0.004 \\
(0.008)\end{array}$ & $\begin{array}{l}-0.015 \\
(0.012)\end{array}$ & $\begin{array}{c}0.005 \\
(0.014)\end{array}$ & $\begin{array}{c}0.000 \\
(0.006)\end{array}$ \\
\hline Domestic Credit $_{\mathrm{i}, \mathrm{t}}$ & $\begin{array}{c}0.000 \\
(0.001)\end{array}$ & $\begin{array}{l}-0.001 \\
(0.001)\end{array}$ & $\begin{array}{c}0.003^{* * *} \\
(0.001)\end{array}$ & $\begin{array}{c}0.043^{* * *} \\
(0.013)\end{array}$ & $\begin{array}{l}0.037^{* *} \\
(0.016)\end{array}$ & $\begin{array}{l}0.055^{* *} \\
(0.022)\end{array}$ & $\begin{array}{c}0.059 * * * \\
(0.019)\end{array}$ & $\begin{array}{l}0.010^{*} \\
(0.006)\end{array}$ \\
\hline Capital Openness $s_{i, t}$ & $\begin{array}{l}-0.000 \\
(0.001)\end{array}$ & $\begin{array}{c}0.002 \\
(0.001)\end{array}$ & $\begin{array}{l}-0.001 \\
(0.001)\end{array}$ & $\begin{array}{l}0.019^{*} \\
(0.010)\end{array}$ & $\begin{array}{c}0.011 \\
(0.015)\end{array}$ & $\begin{array}{c}0.032^{* * *} \\
(0.008)\end{array}$ & $\begin{array}{l}-0.005 \\
(0.025)\end{array}$ & $\begin{array}{c}0.035 * * * \\
(0.005)\end{array}$ \\
\hline Per Capita Income $e_{i, t}$ & $\begin{array}{l}-0.003 \\
(0.002)\end{array}$ & $\begin{array}{l}-0.002 \\
(0.004)\end{array}$ & $\begin{array}{l}-0.006^{*} \\
(0.003)\end{array}$ & $\begin{array}{c}0.087^{* * *} \\
(0.032)\end{array}$ & $\begin{array}{c}0.114^{* * *} \\
(0.037)\end{array}$ & $\begin{array}{c}0.030 \\
(0.038)\end{array}$ & $\begin{array}{c}0.392^{* * *} \\
(0.096)\end{array}$ & $\begin{array}{l}0.028^{*} \\
(0.015)\end{array}$ \\
\hline Real Appreciation ${ }_{i, t}$ & $\begin{array}{c}0.002 \\
(0.002)\end{array}$ & $\begin{array}{l}0.007^{*} \\
(0.004)\end{array}$ & $\begin{array}{c}0.002 \\
(0.003)\end{array}$ & $\begin{array}{c}0.019 \\
(0.025)\end{array}$ & $\begin{array}{c}0.026 \\
(0.029)\end{array}$ & $\begin{array}{c}0.055 \\
(0.052)\end{array}$ & $\begin{array}{c}0.037 \\
(0.071)\end{array}$ & $\begin{array}{c}0.008 \\
(0.012)\end{array}$ \\
\hline Constant & & & & $\begin{array}{c}-9.720^{* *} \\
(3.790)\end{array}$ & $\begin{array}{l}-5.354 \\
(4.595)\end{array}$ & $\begin{array}{c}-15.548^{* *} \\
(6.408)\end{array}$ & $\begin{array}{c}-34.570^{* * *} \\
(10.737)\end{array}$ & $\begin{array}{l}-0.517 \\
(1.971)\end{array}$ \\
\hline Estimation & Probit & Probit & Probit & Pooled OLS & Pooled OLS & Pooled OLS & Pooled OLS & Pooled OLS \\
\hline Observations & 862 & 381 & 481 & 862 & 547 & 315 & 381 & 481 \\
\hline R-squared & 0.129 & 0.059 & 0.236 & 0.198 & 0.176 & 0.262 & 0.207 & 0.354 \\
\hline
\end{tabular}


Table 13: Sensitivity Test Using Domestic Credit Growth

\begin{tabular}{|c|c|c|c|c|c|c|c|c|}
\hline VARIABLES & $\begin{array}{c}\text { (1) } \\
\text { All } \\
\text { Economies }\end{array}$ & $\begin{array}{c}\text { (2) } \\
\text { Advanced } \\
\text { Economies }\end{array}$ & $\begin{array}{c}(3) \\
\text { Emerging } \\
\text { Economies }\end{array}$ & All Surges & $\begin{array}{c}\text { (5) } \\
\text { Surges } \\
\text { Leading to } \\
\text { Normal }\end{array}$ & $\begin{array}{c}\text { (6) } \\
\text { Surges } \\
\text { Leading to } \\
\text { Stop }\end{array}$ & $\begin{array}{c}\text { (7) } \\
\text { All Surges } \\
\text { Advanced }\end{array}$ & $\begin{array}{c}\text { (8) } \\
\text { All Surges } \\
\text { Emerging }\end{array}$ \\
\hline Global Growth $_{\mathrm{t}}$ & $\begin{array}{l}0.042 * \\
(0.022)\end{array}$ & $\begin{array}{l}-0.038 \\
(0.032)\end{array}$ & $\begin{array}{c}0.122^{* * *} \\
(0.034)\end{array}$ & $\begin{array}{c}0.103 \\
(0.206)\end{array}$ & $\begin{array}{c}0.047 \\
(0.258)\end{array}$ & $\begin{array}{c}0.228 \\
(0.413)\end{array}$ & $\begin{array}{l}-0.665 \\
(0.490)\end{array}$ & $\begin{array}{l}0.311^{* *} \\
(0.122)\end{array}$ \\
\hline Global Interest Rate $_{\mathrm{t}}$ & $\begin{array}{c}0.000 \\
(0.002)\end{array}$ & $\begin{array}{l}-0.000 \\
(0.002)\end{array}$ & $\begin{array}{l}-0.001 \\
(0.003)\end{array}$ & $\begin{array}{l}-0.024 \\
(0.016)\end{array}$ & $\begin{array}{c}-0.043^{* * *} \\
(0.013)\end{array}$ & $\begin{array}{c}0.016 \\
(0.037)\end{array}$ & $\begin{array}{c}-0.057^{* * *} \\
(0.021)\end{array}$ & $\begin{array}{l}-0.001 \\
(0.010)\end{array}$ \\
\hline Global Liquidity Growth $_{\mathrm{t}}$ & $\begin{array}{c}0.003 \\
(0.002)\end{array}$ & $\begin{array}{l}-0.002 \\
(0.003)\end{array}$ & $\begin{array}{l}0.007^{*} \\
(0.004)\end{array}$ & $\begin{array}{l}-0.027 \\
(0.028)\end{array}$ & $\begin{array}{l}-0.052 \\
(0.035)\end{array}$ & $\begin{array}{l}-0.035 \\
(0.039)\end{array}$ & $\begin{array}{l}-0.027 \\
(0.048)\end{array}$ & $\begin{array}{c}0.030 \\
(0.021)\end{array}$ \\
\hline Global Commodity Price $_{t}$ & $\begin{array}{c}0.002 \\
(0.006)\end{array}$ & $\begin{array}{c}0.006 \\
(0.011)\end{array}$ & $\begin{array}{c}0.000 \\
(0.009)\end{array}$ & $\begin{array}{c}0.077 \\
(0.069)\end{array}$ & $\begin{array}{c}0.018 \\
(0.091)\end{array}$ & $\begin{array}{c}0.174 \\
(0.119)\end{array}$ & $\begin{array}{l}0.388^{* *} \\
(0.173)\end{array}$ & $\begin{array}{l}-0.058 \\
(0.039)\end{array}$ \\
\hline Global Risk Aversion $_{\mathrm{t}}$ & $\begin{array}{l}-0.008^{* *} \\
(0.003)\end{array}$ & $\begin{array}{l}-0.007 \\
(0.004)\end{array}$ & $\begin{array}{l}-0.007 \\
(0.005)\end{array}$ & $\begin{array}{l}-0.069^{* *} \\
(0.031)\end{array}$ & $\begin{array}{l}-0.059 \\
(0.036)\end{array}$ & $\begin{array}{l}-0.078 \\
(0.061)\end{array}$ & $\begin{array}{l}-0.133^{* *} \\
(0.067)\end{array}$ & $\begin{array}{l}-0.026 \\
(0.021)\end{array}$ \\
\hline Domestic Output Gap ${ }_{\mathrm{i}, \mathrm{t}}$ & $\begin{array}{c}0.086^{* * *} \\
(0.011)\end{array}$ & $\begin{array}{c}0.062^{* * *} \\
(0.021)\end{array}$ & $\begin{array}{c}0.104^{* * *} \\
(0.014)\end{array}$ & $\begin{array}{l}0.266^{* *} \\
(0.115)\end{array}$ & $\begin{array}{l}-0.036 \\
(0.178)\end{array}$ & $\begin{array}{c}0.435^{* * *} \\
(0.146)\end{array}$ & $\begin{array}{l}0.826^{*} \\
(0.424)\end{array}$ & $\begin{array}{c}0.321^{* * *} \\
(0.061)\end{array}$ \\
\hline Market Capitalisation ${ }_{i, t}$ & $\begin{array}{l}0.001^{* *} \\
(0.000)\end{array}$ & $\begin{array}{c}0.000 \\
(0.001)\end{array}$ & $\begin{array}{l}0.001^{*} \\
(0.001)\end{array}$ & $\begin{array}{l}0.006^{*} \\
(0.004)\end{array}$ & $\begin{array}{c}0.004 \\
(0.005)\end{array}$ & $\begin{array}{c}0.008 \\
(0.005)\end{array}$ & $\begin{array}{c}0.002 \\
(0.012)\end{array}$ & $\begin{array}{c}0.005 \\
(0.004)\end{array}$ \\
\hline Domestic Credit Growth $_{\mathrm{i}, \mathrm{t}}$ & $\begin{array}{l}-0.006 \\
(0.006)\end{array}$ & $\begin{array}{l}-0.011 \\
(0.008)\end{array}$ & $\begin{array}{l}-0.001 \\
(0.011)\end{array}$ & $\begin{array}{c}0.667^{* * *} \\
(0.175)\end{array}$ & $\begin{array}{c}0.730^{* * *} \\
(0.215)\end{array}$ & $\begin{array}{l}0.457^{* *} \\
(0.232)\end{array}$ & $\begin{array}{c}1.250^{* * *} \\
(0.297)\end{array}$ & $\begin{array}{l}0.084^{* *} \\
(0.038)\end{array}$ \\
\hline Capital Openness $s_{i, t}$ & $\begin{array}{c}0.000 \\
(0.001)\end{array}$ & $\begin{array}{c}0.002 \\
(0.001)\end{array}$ & $\begin{array}{l}-0.001 \\
(0.001)\end{array}$ & $\begin{array}{l}0.022^{* *} \\
(0.009)\end{array}$ & $\begin{array}{c}0.018 \\
(0.012)\end{array}$ & $\begin{array}{c}0.028^{* * *} \\
(0.009)\end{array}$ & $\begin{array}{l}0.045 * * \\
(0.020)\end{array}$ & $\begin{array}{c}0.032^{* * *} \\
(0.005)\end{array}$ \\
\hline Per Capita Income & $\begin{array}{l}-0.002 \\
(0.002)\end{array}$ & $\begin{array}{l}-0.002 \\
(0.005)\end{array}$ & $\begin{array}{l}-0.001 \\
(0.003)\end{array}$ & $\begin{array}{c}0.126^{* * *} \\
(0.028)\end{array}$ & $\begin{array}{c}0.119^{* * *} \\
(0.033)\end{array}$ & $\begin{array}{c}0.131^{* * *} \\
(0.042)\end{array}$ & $\begin{array}{l}0.171^{* *} \\
(0.082)\end{array}$ & $\begin{array}{c}0.044^{* * *} \\
(0.013)\end{array}$ \\
\hline Real Appreciation ${ }_{i, t}$ & $\begin{array}{c}0.002 \\
(0.002)\end{array}$ & $\begin{array}{l}0.007^{*} \\
(0.004)\end{array}$ & $\begin{array}{c}0.001 \\
(0.003)\end{array}$ & $\begin{array}{c}0.014 \\
(0.024)\end{array}$ & $\begin{array}{c}0.030 \\
(0.030)\end{array}$ & $\begin{array}{c}0.003 \\
(0.042)\end{array}$ & $\begin{array}{c}0.009 \\
(0.061)\end{array}$ & $\begin{array}{c}0.011 \\
(0.012)\end{array}$ \\
\hline Constant & & & & $\begin{array}{c}-11.089 * * * \\
(4.213)\end{array}$ & $\begin{array}{l}-7.424 \\
(5.216)\end{array}$ & $\begin{array}{c}-16.824^{* *} \\
(6.907)\end{array}$ & $\begin{array}{c}-27.199 * * \\
(10.757)\end{array}$ & $\begin{array}{l}-0.954 \\
(2.159)\end{array}$ \\
\hline Estimation & Probit & Probit & Probit & Pooled OLS & Pooled OLS & Pooled OLS & Pooled OLS & Pooled OLS \\
\hline $\begin{array}{l}\text { Observations } \\
\text { R-squared }\end{array}$ & $\begin{array}{c}859 \\
0.139\end{array}$ & $\begin{array}{c}379 \\
0.064\end{array}$ & $\begin{array}{c}480 \\
0.228\end{array}$ & $\begin{array}{c}859 \\
0.237\end{array}$ & $\begin{array}{c}547 \\
0.262\end{array}$ & $\begin{array}{c}312 \\
0.208\end{array}$ & $\begin{array}{c}379 \\
0.305\end{array}$ & $\begin{array}{c}480 \\
0.357\end{array}$ \\
\hline
\end{tabular}

Notes: Columns (1) to (3) show the marginal effects (at means) of probit estimates for the occurrence of surges ending in stops for the all, advanced and emerging economies. Dependent variables for Columns (1) to (3) are dummy variable which takes the value of 1 if surges lead to stops and 0 for surges ending in normal episode. R-squared refers to Pseudo R-squared. Columns (4) to (6) test the significance of global and domestic factors on the magnitude of gross inflows for surges and its two types. Columns (7) and (8) present the results for all surges split by economy types. Dependent variables for Columns (4) to (8) are gross capital inflows in percent of nominal GDP conditional on being in surge types. Standard errors are in parentheses. ${ }^{* * *} p<0.01,{ }^{* *} p<0.05, * p<0.1$. 


\section{Appendix 1: Dataset on Capital Inflows}

The primary source for the quarterly gross capital inflows data is the Balance of Payments Statistics presented in the International Monetary Fund's (IMF) International Financial Statistics (IFS). We access the data from CEIC Database. We define gross capital inflows to include foreign direct investment liabilities, portfolio investment liabilities and other investment liabilities. Our primary period coverage runs from 1970 Q 1 to 2014 Q 4 for 55 economies. Table A1 presents the list countries and their classification along with the dates when quarterly data are first available.

Table A1: Country Sample

\begin{tabular}{|c|c|c|c|}
\hline \multicolumn{2}{|c|}{ Advanced Economies } & \multicolumn{2}{|c|}{ Emerging Economies } \\
\hline Economies & Start & Economies & Start \\
\hline Australia & 1Q1970 & Argentina & 1Q1976 \\
\hline Austria & 1Q1970 & Bangladesh & 1Q1976 \\
\hline Canada & 1Q1970 & Bolivia & 1Q1988 \\
\hline Denmark & 1Q1975 & Brazil & 1Q1975 \\
\hline Finland & 1Q1975 & Chile & 1Q1987 \\
\hline France & 1Q1975 & Colombia & 1Q1992 \\
\hline Germany & 1Q1971 & Croatia & 1Q1993 \\
\hline Greece & 1Q1976 & Czech Republic & 1Q1993 \\
\hline Iceland & 1Q1976 & Estonia & 1Q1992 \\
\hline Ireland & 1Q1981 & Hungary & 4Q1989 \\
\hline Italy & 1Q1970 & India & 1Q1975 \\
\hline Japan & 1Q1977 & Indonesia & 1Q1981 \\
\hline Netherlands & 1Q1970 & Israel & 1Q1972 \\
\hline New Zealand & 1Q1980 & Jordan & 1Q1977 \\
\hline Norway & 1Q1975 & Korea & 1Q1976 \\
\hline Portugal & 1Q1975 & Latvia & 1Q1993 \\
\hline Spain & 1Q1975 & Lithuania & 1Q1993 \\
\hline Sweden & 1Q1975 & Mexico & 1Q1979 \\
\hline United Kingdom & 1Q1970 & Moldova & 1Q1994 \\
\hline \multirow[t]{16}{*}{ United States } & 1Q1973 & Pakistan & 1Q1976 \\
\hline & & Peru & 1Q1977 \\
\hline & & Philippines & 1Q1977 \\
\hline & & Poland & 1Q1985 \\
\hline & & Romania & 1Q1991 \\
\hline & & Russia & 1Q1994 \\
\hline & & Singapore & 1Q1986 \\
\hline & & Slovakia & 1Q1993 \\
\hline & & Slovenia & 1Q1992 \\
\hline & & South Africa & 1Q1985 \\
\hline & & Sri Lanka & 1Q1977 \\
\hline & & Taiwan & 1Q1981 \\
\hline & & Thailand & 1Q1976 \\
\hline & & Turkey & 1Q1984 \\
\hline & & Ukraine & 1Q1994 \\
\hline & & Venezuela & 1Q1990 \\
\hline
\end{tabular}

Several modifications are made to make the dataset usable and consistent.

- We select countries closely following the sample of Forbes and Warnock (2012a and 2012b). However, we exclude Belgium-Luxembourg, Guatemala, Hong Kong, Malaysia, Nicaragua, Panama, and Switzerland because they either have short period coverage or limited data availability for capital inflows. But we add four countries to increase the sample size. These 
countries have longer quarterly gross capital flows data available. They include Jordan, Moldova, Pakistan, and Ukraine.

- IFS reports some values in billions of U.S. dollars, while most are in millions of U.S. dollars. Although the reported unit will not affect the identification of episodes, all values are converted to millions of U.S. dollars for consistency.

- Quarterly data before 2012Q1 follows the IMF's Balance of Payments Manual 5; while data from 2012Q1 onwards follows Balance of Payment Manual 6. The signs of gross inflows categories were made consistent to that using Balance of Payments Manual 5. No attempt was made to reconcile both series as small categorical changes are made for financial account liabilities, mostly involving intra-category changes for foreign direct investment liabilities. The transition from BPM5 to BPM6 does not affect our computed aggregate gross capital inflows.

- Data for Taiwan is sourced from the Central Bank of the Republic of China (Taiwan) accessed through CEIC Database.

- For some countries, data points are extended to increase the available periods in computing for rolling mean and standard deviation. Quarterly data for Chile (1987Q1-1990Q4), Colombia (1992Q1-1995Q4), and Venezuela (1990Q1-1993Q4) are computed by dividing the annual values sourced from the IFS by four. This modification departs from Forbes and Warnock (2012a and 2012b) approach where they do not extend the series for some countries. A justification for extending the series by four years for some countries is that the actual dating of an episode will start after the fourth year or $17^{\text {th }}$ quarter from the start of available data. The extended data points will in effect be used only for computing the rolling mean and rolling standard deviation.

- Data gaps for Greece (1998Q1-1998Q4), Norway (1992Q1-1993Q4), Peru (1985Q1-1990Q4), Poland (1996Q1-1999Q4), and Slovakia (2001Q1-2001Q4) are filled in by using annual values sourced from the IFS or from national sources divided by four. Data gaps are filled in to generate continuous series needed to calculate rolling standard deviation and mean for episode identification.

- Unlike Forbes and Warnock (2012a and 2012b), we do not make adjustments to fill in data gaps in the series. Forbes and Warnock (2012a and 2012b) replace interior missing data with zeros if the string of missing values is surrounded with zeros or other values; and/or used data on net error and omissions to fill in the gaps. In this paper, no adjustments are made so as to consider only those classified financial transactions from the Balance of Payments.

- Similar to Forbes and Warnock (2012a and 2012b), our computed inflows exclude financial derivative liabilities as unlike other debt instruments, no principal amount is advanced to be repaid and no investment income accrues for derivatives. 
Table A2: Surge Episodes in Advanced Economies

\begin{tabular}{|c|c|c|c|c|c|}
\hline Economy & $\begin{array}{c}\text { Surges Leading } \\
\text { to Normal }\end{array}$ & $\begin{array}{c}\text { Surges Leading } \\
\text { to Stops }\end{array}$ & Economy & $\begin{array}{c}\text { Surges Leading } \\
\text { to Normal }\end{array}$ & $\begin{array}{c}\text { Surges Leading } \\
\text { to Stops }\end{array}$ \\
\hline \multirow[t]{4}{*}{ Australia } & $1993 q 4-1994 q 3$ & $1982 q 4$ & & $1995 q 3-1996 q 3$ & \\
\hline & $1999 q 3-1999 q 4$ & 1988q4-1989q1 & & 1997q4-1999q1 & \\
\hline & $2002 q 3-2002 q 4$ & $1995 q 3-1996 q 3$ & & $2003 q 3-2004 q 2$ & \\
\hline & 2006q1-2007q1 & $2003 q 4-2004 q 3$ & & $2014 q 2-2014 q 4$ & \\
\hline \multirow[t]{2}{*}{ Austria } & 1992q2-1993q1 & $1999 q 2-2000 q 1$ & \multirow[t]{3}{*}{ Italy } & $2002 q 4-2003 q 4$ & \multirow[t]{3}{*}{ 1990q3-1991q1 } \\
\hline & $2003 q 4-2005 q 4$ & & & $2005 q 2-2006 q 1$ & \\
\hline \multirow[t]{3}{*}{ Canada } & $1996 q 4-1997 q 3$ & & & $2010 q 4-2011 q 3$ & \\
\hline & $2000 q 1-2001 q 1$ & & \multirow[t]{3}{*}{ Japan } & $1986 q 2-1987 q 3$ & \\
\hline & $2006 q 2-2007 q 1$ & & & $1993 q 4-1995 q 1$ & \\
\hline Denmark & $2005 q 1-2005 q 4$ & $1985 q 4-1986 q 2$ & & $2009 q 4-2011 q 1$ & \\
\hline \multirow[t]{5}{*}{ Finland } & 1987q1-1987q4 & 1984q3-1985q1 & \multirow{2}{*}{ Netherlands } & 1997q4-1998q4 & \\
\hline & $1996 q 3-1997 q 3$ & $2011 q 3-2011 q 4$ & & $2005 q 2-2006 q 2$ & \\
\hline & 1998q4-1999q1 & & \multirow[t]{2}{*}{ New Zealand } & \multirow[t]{2}{*}{ 2000q2-2001q1 } & 1986q3-1987q2 \\
\hline & $2004 q 3-2004 q 4$ & & & & $2006 q 3-2007 q 3$ \\
\hline & $2010 q 2-2010 q 3$ & & \multirow{4}{*}{ Norway } & 1984q3-1985q3 & $1982 q 4$ \\
\hline \multirow[t]{3}{*}{ France } & $1986 q 3-1987 q 4$ & 2001q1-2001q2 & & 1992q3-1993q2 & 1996q4-1997q1 \\
\hline & 1989q1-1989q4 & & & $2002 q 4-2003 q 2$ & $2000 q 3-2000 q 4$ \\
\hline & 1997q4-1998q3 & & & & $2005 q 4-2007 q 1$ \\
\hline \multirow[t]{3}{*}{ Germany } & 1989q2-1990q1 & 1986q1-1986q4 & \multirow{3}{*}{ Portugal } & 1988q4-1990q2 & $2003 q 4-2004 q 2$ \\
\hline & $2005 q 1-2005 q 4$ & $1992 q 3-1993 q 3$ & & $1994 q 3-1995 q 3$ & $2009 q 4-2010 q 2$ \\
\hline & & $2007 q 2-2008 q 1$ & & $2000 q 1-2000 q 4$ & \\
\hline \multirow[t]{4}{*}{ Greece } & 1998q2-1999q1 & 1989q4-1991q1 & \multirow{3}{*}{ Spain } & 1987q1-1988q2 & 1993q2-1993q4 \\
\hline & $2002 q 2-2003 q 1$ & 1995q1-1995q2 & & 1990q4-1991q3 & 2000q3-2001q1 \\
\hline & \multirow[t]{2}{*}{$2007 q 1-2007 q 4$} & 1996q3-1997q1 & & $2014 q 2-2014 q 4$ & \\
\hline & & $2005 q 1-2005 q 3$ & \multirow[t]{2}{*}{ Sweden } & $1985 q 3-1987 q 3$ & \multirow[t]{2}{*}{$1989 q 2-1990 q 4$} \\
\hline \multirow[t]{4}{*}{ Iceland } & 1987q1-1987q4 & & & $2004 q 4-2005 q 3$ & \\
\hline & $1995 q 4-1996 q 4$ & & \multirow[t]{3}{*}{ United Kingdom } & \multirow[t]{3}{*}{$1985 q 3-1987 q 2$} & 1992q2-1993q4 \\
\hline & $1998 q 3-1999 q 4$ & & & & $2000 q 3-2000 q 4$ \\
\hline & $2003 q 3-2006 q 1$ & & & & $2007 q 2-2007 q 4$ \\
\hline \multirow[t]{3}{*}{ Ireland } & $1986 q 4-1987 q 3$ & $2006 q 3-2007 q 3$ & \multirow[t]{3}{*}{ United States } & \multirow{3}{*}{$\begin{array}{l}1986 q 1-1986 q 4 \\
1993 q 3-1994 q 3\end{array}$} & 1997q1-1997q3 \\
\hline & $1989 q 3-1990 q 2$ & & & & 1999q4-2000q3 \\
\hline & $1992 q 3-1993 q 4$ & & & & $2006 q 4-2007 q 2$ \\
\hline
\end{tabular}

Notes: Dating of surge episodes follows Forbes and Warnock (2012a and 2012b). Surge episode for Australia and Norway in 1982Q4 pertains to the last quarter for that surge period. 
Table A3: Surge Episodes in Emerging Economies

\begin{tabular}{|c|c|c|c|c|c|}
\hline Economy & $\begin{array}{c}\text { Surges Leading } \\
\text { to Normal }\end{array}$ & $\begin{array}{c}\text { Surges Leading } \\
\text { to Stops }\end{array}$ & Economy & $\begin{array}{c}\text { Surges Leading } \\
\text { to Normal }\end{array}$ & $\begin{array}{c}\text { Surges Leading } \\
\text { to Stops }\end{array}$ \\
\hline Argentina & 1990q3-1992q3 & & Latvia & $2003 q 3-2005 q 1$ & $2006 q 2-2007 q 4$ \\
\hline \multirow[t]{5}{*}{ Bangladesh } & 1989q1-1989q4 & \multirow{5}{*}{ 2010q1-2010q2 } & Lithuania & $2004 q 2-2004 q 3$ & $2005 q 4-2008 q 1$ \\
\hline & 1998q1-1998q3 & & Mexico & 1989q2-1991q2 & $2007 q 3-2008 q 2$ \\
\hline & $2003 q 4-2004 q 1$ & & Moldova & & $2006 q 4-2008 q 3$ \\
\hline & $2005 q 1-2005 q 2$ & & \multirow[t]{5}{*}{ Pakistan } & 1985q3-1986q2 & \multirow[t]{5}{*}{$2005 q 1-2007 q 3$} \\
\hline & $2012 q 2-2013 q 2$ & & & 1988q2-1989q1 & \\
\hline \multirow[t]{2}{*}{ Bolivia } & 1996q1-1996q3 & \multirow[t]{2}{*}{ 1997q4-1998q4 } & & 1992q4-1993q3 & \\
\hline & $2007 q 2-2008 q 4$ & & & 2001q1-2001q4 & \\
\hline \multirow[t]{3}{*}{ Brazil } & 1990q2-1991q1 & 1994q1-1994q3 & & $2013 q 1-2014 q 4$ & \\
\hline & $1992 q 2-1992 q 3$ & \multirow{2}{*}{$2006 q 3-2007 q 4$} & Peru & 1990q4-1992q3 & $2006 q 4-2008 q 2$ \\
\hline & $1995 q 3-1996 q 2$ & & & $1994 q 2-1995 q 1$ & \\
\hline Chile & $2005 q 4-2006 q 3$ & $2007 q 4-2008 q 3$ & \multirow[t]{3}{*}{ Philippines } & \multirow[t]{3}{*}{$1994 q 2-1994 q 3$} & 1996q1-1997q1 \\
\hline \multirow[t]{2}{*}{ Colombia } & $2005 q 4-2006 q 3$ & & & & $2005 q 2-2005 q 4$ \\
\hline & $2010 q 4-2011 q 2$ & & & & $2006 q 4-2007 q 3$ \\
\hline Croatia & & $2002 q 4-2003 q 4$ & Poland & $2003 q 4-2004 q 4$ & $2007 q 1-2008 q 2$ \\
\hline Czech Republic & $2002 q 3-2003 q 1$ & & \multirow{3}{*}{ Romania } & 1996q4-1997q3 & \multirow[t]{3}{*}{$2006 q 4-2007 q 4$} \\
\hline \multirow[t]{2}{*}{ Estonia } & \multirow[t]{2}{*}{$2003 q 1-2005 q 1$} & 1997q4-1998q1 & & $2000 q 4-2001 q 2$ & \\
\hline & & 2007q1-2007q4 & & $2004 q 1-2005 q 3$ & \\
\hline \multirow[t]{3}{*}{ Hungary } & $2002 q 4-2003 q 4$ & & Russia & & 2007q1-2008q1 \\
\hline & $2005 q 1-2005 q 3$ & & \multirow[t]{2}{*}{ Singapore } & \multirow[t]{2}{*}{ 1995q2-1996q1 } & 1997q1-1997q2 \\
\hline & $2006 q 3-2008 q 1$ & & & & $2006 q 4-2007 q 4$ \\
\hline \multirow[t]{5}{*}{ India } & 1984q1-1985q2 & \multirow{5}{*}{ 2006q4-2008q1 } & Slovakia & $2013 q 2-2014 q 1$ & $2004 q 3-2005 q 2$ \\
\hline & 1987q1-1987q3 & & Slovenia & $2002 q 3-2003 q 3$ & 2007q1-2007q4 \\
\hline & 1993q4-1994q4 & & \multirow[t]{2}{*}{ South Africa } & 1994q3-1995q4 & \multirow[t]{2}{*}{ 1997q2-1998q1 } \\
\hline & 1996q2-1997q1 & & & $2003 q 4-2006 q 2$ & \\
\hline & $2003 q 3-2005 q 3$ & & \multirow{2}{*}{ Sri Lanka } & 1989q3-1990q3 & \multirow[t]{2}{*}{$1982 q 4-1983 q 2$} \\
\hline \multirow[t]{3}{*}{ Indonesia } & 1990q3-1991q2 & \multirow{3}{*}{$2005 q 4-2006 q 1$} & & $2011 q 1-2013 q 2$ & \\
\hline & $1995 q 2-1996 q 2$ & & \multirow[t]{2}{*}{ Taiwan } & $2003 q 3-2004 q 2$ & 1986q4-1987q2 \\
\hline & $2009 q 4-2010 q 4$ & & & $2009 q 3-2010 q 3$ & $1999 q 2-2000 q 2$ \\
\hline Israel & 1989q3-1990q3 & & Thailand & 1987q4-1990q2 & 1995q2-1996q1 \\
\hline & 1999q1-2000q1 & & & & $2004 q 3-2006 q 1$ \\
\hline & 2006q1-2006q4 & & Turkey & 1990q1-1990q4 & 1992q3-1993q4 \\
\hline & $2012 q 4-2013 q 3$ & & & & $2000 q 1-2000 q 3$ \\
\hline Jordan & $2004 q 4-2005 q 4$ & 1991q2-1992q1 & Ukraine & & $2004 q 1-2008 q 2$ \\
\hline & $2013 q 1-2013 q 4$ & & Venezuela & 1996q3-1998q1 & $2005 q 1-2005 q 4$ \\
\hline Korea & 1988q1-1989q1 & $2006 q 2-2007 q 2$ & & 2007q1-2008q1 & \\
\hline & $1994 q 3-1995 q 4$ & & & & \\
\hline & $2009 q 3-2010 q 2$ & & & & \\
\hline
\end{tabular}




\section{References}

Accominotti, O. and B. Eichengreen. 2013. The Mother of All Sudden Stops: Capital Flows and Reversals in Europe, 1919-1932. Berkeley Economic History Working Paper 2013/7.

Fernandez-Arias, E. 1996. The New Wave of Private Capital Inflows: Push or Pull? Journal of Development Economics. 48: 389-418.

Balakrishnan R., S. Nowak, S. Panth, and Y. Wu. 2013. Surging Capital Flows to Emerging Asia: Facts, Impacts and Responses. Journal of International Commerce, Economics and Policy, 4 (2).

Benigno, G., N. Converse, and L. Fornaro. 2015. Large Capital Inflows, Sectoral Allocation, and Economic Performance. Journal of International Money and Finance, 55: 60-87.

Caballero, J. 2014. Do Surges in International Capital Inflows Influence the Likelihood of Banking Crises? The Economic Journal, doi:10.1111/ecoj.12172.

Calderon, C. and M. Kubota. 2013. Sudden Stops: Are Global and Local Investors Alike? Journal of International Economics, 89 (1): 122-142.

Calvo, G. 1998. Capital Flows and Capital-Market Crises: The Simple Economics of Sudden Stops. Journal of Applied Economics, 1: 35-54.

Calvo, G., L. Leiderman, and C. Reinhart. 1993. Capital Inflows and Real Exchange Rate Appreciation in Latin America: The Role of External Factors. IMF Staff Papers, 40(1): 108-151.

Calvo, G., L. Leiderman, and C. Reinhart. 1996. Inflows of Capital to Developing Countries in 1990s. Journal of Economic Perspectives, 10(2): 123-139.

Calvo, G., A. Izquierdo, and L.-F. Mejia. 2008. Systemic Sudden Stops: The Relevance of BalanceSheet Effects and Financial Integration. NBER Working Paper Series 14026.

Calvo, G., A. Izquierdo, and E. Talvi. 2006. Sudden Stops and Phoenix Miracles in Emerging Markets. American Economic Review, 96(2): 405-410.

Cavallo, E. and J. Frankel. 2008. Does Openness to Trade Make Countries More Vulnerable to Sudden Stops, or Less? Using Gravity to Establish Causality. Journal of International Money and Finance, 27: 1430-1452.

Chinn, M. and H. Ito. 2006. What Matters for Financial Development? Capital Controls, Institutions, and Interactions. Journal of Development Economics, 81(1): 163-192.

Chuhan, P., S. Claessens, and N. Mamingi. 1998. Equity and Bond Flows to Latin America and Asia: The Role of Global and Country Factors. Journal of Development Economics, 55: 439-463.

Crystallin M., L. Efremidze, S. Kim, W. Nugroho, O. Sula, and T. Willett. 2015. How Common Are Capital Flows Surges? How They Are Measured Matters A Lot. Open Economics Review, 26: 663-682.

Faucette J., A. Rothenberg, and F. Warnock. 2005. Outflows-Induced Sudden Stops. The Journal of Policy Reform, 8(2): 119-129.

Forbes, K. and F. Warnock. 2012a. Capital Flow Waves, Surges, Stops, Flights and Retrenchment. Journal of International Economics, 88 (2): 235-251.

Forbes, K. and F. Warnock. 2012b. Debt- and Equity-Led Capital Flows Episodes. NBER Working Paper Series 18329.

Fratzscher, M. 2012. Capital Flows, Push versus Pull Factors and the Global Financial Crisis. Journal of International Economics, 88(2): 341-365.

Ghosh, A., J. Kim, M. Qureshi, and J. Zalduendo. 2014. Surges. Journal of International Economics, 92(2): 266-285.

Ghosh, A. J, Ostry, and M. Qureshi. 2016. When Do Capital Inflow Surges End in Tears? American Economic Review, 106(5): 581-585.

Gorton, G. and G. Ordoñez. 2016. Good Booms, Bad Booms. NBER Working Paper Series 22008.

International Monetary Fund. 2011. Recent Experiences in Managing Capital Inflows - Cross-Cutting Themes and Possible Policy Framework. Washington D.C.

Kim, Singsoo, L. Efremidze, O. Sula, and T. Willet. 2014. The Relationships Among Capital Flows Surges, Reversals, and Sudden Stops. Mimeo. 
Koepke, R. 2015. What Drives Capital Flows to Emerging Markets? A Survey of Empirical Literature. Institute for International Financial Working Paper.

Magud, N., C. Reinhart, and E. Vesperoni. 2014. Capital Inflows, Exchange Rate Flexibility, and Credit Booms. Review of Development Economics, 18(3): 415-430.

Milesi-Ferretti, G.-M. and C. Tille. 2011. The Great Retrenchment: International Capital Flows during the Global Financial Crisis. Economic Policy, 26(66): 285-342.

Reinhart, C. and V. Reinhart. 2009. Capital Flow Bonanzas: An Encompassing View of the Past and Present. NBER International Seminar on Macroeconomics 2008.

Rothenberg, A. and F. Warnock. 2011. Sudden Flight and True Sudden Stops. Review of International Economics, 19(3): 509-524.

Sula, O. 2010. Surges and Sudden Stops of Capital Flows to Emerging Markets. Open Economics Review, 21:589-605. 